Review

\title{
Hydrogen Sulfide: From a Toxic Molecule to a Key Molecule of Cell Life
}

\author{
Angeles Aroca ${ }^{1,2}, * \mathbb{C}$, Cecilia Gotor ${ }^{2}\left(\mathbb{D}\right.$, Diane C. Bassham ${ }^{1}\left(\mathbb{D}\right.$ and Luis C. Romero ${ }^{2}$ \\ 1 Department of Genetics, Development and Cell Biology, Iowa State University, Ames, IA 50011, USA; \\ bassham@iastate.edu \\ 2 Institute of Plant Biochemistry and Photosynthesis, University of Seville and CSIC, 41092 Seville, Spain; \\ gotor@ibvf.csic.es (C.G.); lromero@ibvf.csic.es (L.C.R.) \\ * Correspondence: aaroca@us.es
}

Received: 2 June 2020; Accepted: 13 July 2020; Published: 15 July 2020

check for updates

\begin{abstract}
Hydrogen sulfide $\left(\mathrm{H}_{2} \mathrm{~S}\right)$ has always been considered toxic, but a huge number of articles published more recently showed the beneficial biochemical properties of its endogenous production throughout all regna. In this review, the participation of $\mathrm{H}_{2} \mathrm{~S}$ in many physiological and pathological processes in animals is described, and its importance as a signaling molecule in plant systems is underlined from an evolutionary point of view. $\mathrm{H}_{2} \mathrm{~S}$ quantification methods are summarized and persulfidation is described as the underlying mechanism of action in plants, animals and bacteria. This review aims to highlight the importance of its crosstalk with other signaling molecules and its fine regulation for the proper function of the cell and its survival.
\end{abstract}

Keywords: Hydrogen sulfide; crosstalk; persulfidation; gasotransmitter; signaling molecules; human and plant therapies

\section{Introduction}

Hydrogen sulfide $\left(\mathrm{H}_{2} \mathrm{~S}\right)$ is a flammable, colorless gas with a characteristic odor of rotten eggs. $\mathrm{H}_{2} \mathrm{~S}$ naturally occurs in volcanic gases, natural gas and some well water and is also produced when bacteria break down organic matter in the absence of oxygen. $\mathrm{H}_{2} \mathrm{~S}$ poisoning has mainly been observed in industrial settings. Thus, workers may be exposed to $\mathrm{H}_{2} \mathrm{~S}$ in many industries, including agriculture, petroleum, and sewage processing [1]. $\mathrm{H}_{2} \mathrm{~S}$ is toxic to humans and acute exposure to high amounts of $\mathrm{H}_{2} \mathrm{~S}(>500 \mathrm{ppm}$ ) can lead to death [1]. The first reported biological experiment to study the effect of $\mathrm{H}_{2} \mathrm{~S}$ in animals was published in 1908 and described the lethal effects of $\mathrm{H}_{2} \mathrm{~S}$ gas when it was absorbed through the skin or directly administered to the stomach or rectum [2]. Since then, hundreds of articles reporting on the toxicological effects of $\mathrm{H}_{2} \mathrm{~S}$ in various species, including humans, different cell types and organs, were published during the last century. This gas has always been considered toxic due to its ability to inhibit mitochondrial respiration through inhibition of cytochrome c oxidase, similar to hydrogen cyanide ( $\mathrm{HCN})$ [3]. Nevertheless, over the last few decades of the past century, several investigations were conducted on the presence of $\mathrm{H}_{2} \mathrm{~S}$ as an endogenous product in bacteria and mammals. In the oral microbiota in humans, $\mathrm{H}_{2} \mathrm{~S}$ was found to be responsible for oral halitosis and to be related to periodontal inflammation [4], and in the intestinal microbiota, $\mathrm{H}_{2} \mathrm{~S}$ was found to be a component of flatus [5]. In parallel, several publications conducted detailed characterizations of the biochemical properties of the endogenous production pathways of $\mathrm{H}_{2} \mathrm{~S}$ in different species. The mammalian enzymes responsible for $\mathrm{H}_{2} \mathrm{~S}$ production are cystathionine beta-synthase, CBS; cystathionine gamma-lyase, CSE; and 3-mercaptopyruvate sulfurtransferase, 3-MST [6,7] (Figure 1), which have homologs in other species: in Klebsiella pneumoniae, $\mathrm{CBS}$ is the main source of $\mathrm{H}_{2} \mathrm{~S}$; in E. coli, 3-MST is the main source of $\mathrm{H}_{2} \mathrm{~S}$ under aerobic conditions, while the cysteine desulfurase 
(IscS) is the primary source under anaerobic conditions [8].; Similar to mammals, C. elegans has three $\mathrm{H}_{2}$ S-synthesizing enzymes, CSE, CBS and 3-MST [9-11]. In plants, $\mathrm{H}_{2} \mathrm{~S}$ production was first observed in 1964, when the release of sulfide components in Liliaceous vegetables was described [12], and then, in 1968, Cormis described the emission of $\mathrm{H}_{2} \mathrm{~S}$ from plants after exposure to $\mathrm{SO}_{2}$ [13]. In 1987, two enzymes, L- and D-cysteine desulfhydrases, were found to catalyze the production of $\mathrm{H}_{2} \mathrm{~S}$ in chloroplasts and mitochondria [14] (Figure 1). In recent years, several characterizations of these enzymes have been conducted, revealing detailed $\mathrm{H}_{2} \mathrm{~S}$ biosynthesis and sulfur assimilation pathways in plants $[15,16]$.

\begin{tabular}{|c|c|c|c|c|c|c|c|c|}
\hline Name & \multicolumn{2}{|c|}{ Hydrogen sulfide } & \multicolumn{2}{|c|}{ Nitric oxide } & \multicolumn{2}{|c|}{ Hydrogen peroxide } & \multicolumn{2}{|c|}{ Carbon monoxide } \\
\hline Chemical formula & \multicolumn{2}{|c|}{$\mathrm{H}-\mathrm{S}-\mathrm{H}$} & \multicolumn{2}{|c|}{$\mathrm{N}=\mathrm{O}$} & \multicolumn{2}{|c|}{$\mathrm{HO}-\mathrm{OH}$} & \multicolumn{2}{|c|}{$\mathrm{C}=\mathrm{O}$} \\
\hline $\begin{array}{c}\text { Molecular mass } \\
\left(\mathrm{g} \mathrm{mol}^{-1}\right)\end{array}$ & \multicolumn{2}{|c|}{34.08} & \multicolumn{2}{|c|}{30.01} & \multicolumn{2}{|c|}{34.01} & \multicolumn{2}{|c|}{28.01} \\
\hline Chemical reactivity & \multicolumn{2}{|c|}{ Very high } & \multicolumn{2}{|c|}{ Very high } & \multicolumn{2}{|c|}{ High } & \multicolumn{2}{|c|}{ Moderate } \\
\hline Toxicity concentration & \multicolumn{2}{|c|}{$5-30 \mu \mathrm{M}$} & \multicolumn{2}{|c|}{$0.5-150 \mu \mathrm{M}$} & \multicolumn{2}{|c|}{$0.5-500 \mu \mathrm{M}$} & \multicolumn{2}{|c|}{$30-50 \mathrm{ppm}$} \\
\hline \multirow[b]{2}{*}{ Enzymatic production } & Animals & Plants & Animals & Plants & Animals & Plants & Animals & Plants \\
\hline & $\begin{array}{c}\text { CBS } \\
\text { CSE } \\
\text { 3-MTS }\end{array}$ & $\begin{array}{c}\text { L-/D-DES } \\
\text { CAS } \\
\text { CS } \\
\text { SiR }\end{array}$ & $\begin{array}{l}\text { eNOS } \\
\text { iNOS } \\
\text { nNOS }\end{array}$ & $\begin{array}{l}\text { NRs } \\
\text { NOS? }\end{array}$ & $\begin{array}{l}\text { SOD } \\
\text { POX }\end{array}$ & $\begin{array}{l}\text { PAO } \\
\text { SOD } \\
\text { POX }\end{array}$ & $\mathrm{HO}-1$ & $\mathrm{HO}-1$ \\
\hline Concentration in cells & \multicolumn{2}{|c|}{$n M-\mu M$} & \multicolumn{2}{|c|}{$\mathrm{nM}$} & \multicolumn{2}{|c|}{$\frac{1}{n M-\mu M}$} & \multicolumn{2}{|c|}{$n M-\mu M$} \\
\hline Half life in vivo & \multicolumn{2}{|c|}{ Seconds-minutes } & \multicolumn{2}{|c|}{ seconds } & \multicolumn{2}{|c|}{ Seconds-minutes } & \multicolumn{2}{|c|}{ Minutes } \\
\hline Protein modification & \multicolumn{2}{|c|}{ Persulfidation } & \multicolumn{2}{|c|}{ s-nitrosation } & \multicolumn{2}{|c|}{ s-sulfenylation } & \multicolumn{2}{|c|}{ ? } \\
\hline
\end{tabular}

CBS: cystathionine $\beta$-synthase; CSE:Cystathionine $\gamma$-lyase; 3-MTS: 3-mercaptopyruvate sulfur transferase; L-ID-DES: cysteine desulfhydrase; CAS: $\beta$-cyano-alanine synthase; CS:cysteine synthase; SiR: Sulfito reductasa; NOS: Nitric oxide synthase; NRs: Nitrate reductases; PAO: polyamine oxidase; SOD: Superoxide dismutase; POX: peroxidase; HO-1: Heme oxygenase 1.

Figure 1. Comparison of signaling molecules in plants and mammals. Hydrogen sulfide $\left(\mathrm{H}_{2} \mathrm{~S}\right)$, nitric oxide (NO), hydrogen peroxide $\left(\mathrm{H}_{2} \mathrm{O}_{2}\right)$ and carbon monoxide $(\mathrm{CO})$ are considered to be signaling molecules in diverse and important physiological pathways in cells. These inorganic molecules are endogenously produced by enzymatic pathways and have similar molecular masses but different chemical reactivity.

\section{Physiological Role}

During the past century, $\mathrm{H}_{2} \mathrm{~S}$ was thought to only be a toxic molecule, and it was not until 1990 that Kimura and coworkers revealed its role in essential functions in human physiology, opening a new emerging field in life science [17]. The first physiological assay published in 1996 demonstrated that $\mathrm{H}_{2} \mathrm{~S}$ acts as an endogenous neuromodulator [18]. The participation of $\mathrm{H}_{2} \mathrm{~S}$ in many physiological and pathological processes in animals has been described over the last two decades, including its role in the regulation of cell proliferation, apoptosis, inflammatory processes, hypoxia, neuromodulation, and cardioprotection [19-21]. Therefore, $\mathrm{H}_{2} \mathrm{~S}$ is now accepted as playing roles as a gasotransmitter (gaseous signaling compound) that is as important as nitric oxide (NO) and carbon monoxide (CO) in mammals, and as a signaling molecule that is as important as hydrogen peroxide $\left(\mathrm{H}_{2} \mathrm{O}_{2}\right)$ in plants $[18,22,23]$. The term 'gasotransmitter' was introduced in 2002 to describe these molecules, which share common characteristics: they are endogenously produced, with a signaling role, generated by enzymatic pathways, and permeable to cell membranes; their endogenous biosynthesis may be regulated; and their effect is dose-dependent (Figure 1). The scientific interest in $\mathrm{H}_{2} \mathrm{~S}$ in the past was mainly due to its role in important and devastating human diseases, such as neurodegenerative disorders, including Alzheimer's disease, Parkinson's disease, and vascular dementia [24-26]; Huntington's disease [27]; and cancer [28-30].

Although the first descriptions of the effects of $\mathrm{H}_{2} \mathrm{~S}$ in plants were from the 1960s [31], interest in the role of $\mathrm{H}_{2} \mathrm{~S}$ in plant systems arose later. It was not until the past decade that the effects of $\mathrm{H}_{2} \mathrm{~S}$ were 
described in seed germination [32], the number and length of adventitious roots [33] and the regulation of genes involved in photosynthesis [34]. Thereafter, the protective effects of exogenous $\mathrm{H}_{2} \mathrm{~S}$ against different stresses were documented, such as protection against oxidative and metal stresses [32,35-40], drought and heat tolerance [39,41], and osmotic and saline stresses [42]. Thus, publications on these dose-dependent effects of $\mathrm{H}_{2} \mathrm{~S}$ have emerged, postulating $\mathrm{H}_{2} \mathrm{~S}$ to be an important signaling molecule that has analogous functions in plant systems to those previously described in mammals. $\mathrm{H}_{2} \mathrm{~S}$ was also shown to be a regulator of other important physiological processes in plants, such as stomatal closure/aperture [43-46]; thus, its importance in drought stress relief is due to the ability of $\mathrm{H}_{2} \mathrm{~S}$ to induce stomatal closure in Arabidopsis thaliana [46,47]. Another positive effect of $\mathrm{H}_{2} \mathrm{~S}$ was described by Dooley et al., who showed that low doses of $\mathrm{H}_{2} \mathrm{~S}$ strongly affected plant metabolism, improved germination, caused significant plant growth and increased biomass, leading to a higher fruit yield [48]. $\mathrm{H}_{2} \mathrm{~S}$ has also been shown to be involved in the regulation of flower senescence in plants [49], in lateral root formation in tomato mediated by auxin-regulation [50] and in nicotine biosynthesis in tobacco [51].

More recently, there has been increasing interest in the effect of $\mathrm{H}_{2} \mathrm{~S}$ on autophagy regulation in the scientific community. In mammals, the protective effect of $\mathrm{H}_{2} \mathrm{~S}$ against some of the diseases mentioned above has been linked with the regulation of autophagy [52,53]. Autophagy is a cellular catabolic pathway that is evolutionarily conserved from yeast to mammals, and it involves the digestion of cell contents to recycle nutrients or to degrade damaged or toxic components. The AMP-dependent kinase (AMPK) and mammalian target of rapamycin (mTOR) pathways play important roles in the control of autophagy. To this end, activation of AMPK or inhibition of mTOR has been shown to activate autophagy [54]. Exposure to $\mathrm{H}_{2} \mathrm{~S}$ has been shown to cause a significant increase in AMPK phosphorylation, which increases its activity and inhibits the activation of downstream targets, such as mTOR [55]. In plants, $\mathrm{H}_{2} \mathrm{~S}$ was shown to inhibit autophagy by preventing ATG8 (autophagy-related ubiquitin-like protein) accumulation [56]. $\mathrm{H}_{2} \mathrm{~S}$ is able to inhibit starvation-induced autophagy in Arabidopsis roots, and this repression is independent of redox conditions [57].

The first mechanism proposed for $\mathrm{H}_{2} \mathrm{~S}$ was based on its chemical properties, since this nucleophilic molecule is able to react with reactive oxygen/nitrogen species and reduce the cellular oxidative state [58,59]. In addition, $\mathrm{H}_{2} \mathrm{~S}$ is able to regulate several antioxidant enzymes, such as ascorbate peroxidase (APX) [60-62], catalase (CAT) [63,64], superoxide dismutase (SOD) [63,65], and glutathione reductase (GR) [62], and non-enzymatic compounds, such as the glutathione anti-oxidant pool [66,67].

The antioxidant role of $\mathrm{H}_{2} \mathrm{~S}$ has been the focus of numerous studies in mammalian systems as a critical mediator of multiple pathophysiological processes [68]. In plants, the number of studies on the effects of $\mathrm{H}_{2} \mathrm{~S}$ in the model plant Arabidopsis has increased in recent years; in addition, the effects of $\mathrm{H}_{2} \mathrm{~S}$ in agricultural crops are relevant as an exogenous treatment to cope with economic loss due to environmental stress. The effects of exogenous (pre-)treatment with water-soluble donors of $\mathrm{H}_{2} \mathrm{~S}$ have been the focus of numerous studies in several agricultural species. Fotopoulos et al. have reviewed these studies regarding the effects of $\mathrm{H}_{2} \mathrm{~S}$ on plant growth, its ability to improve resistance against abiotic and biotic stress, and its positive postharvest effects [69]. Thus, a better understanding of the mechanism of action of $\mathrm{H}_{2} \mathrm{~S}$ is important to fight against crop loss. This knowledge would help in agricultural sustainability and in producing the food required by the increasing world population [70].

\section{Quantification Methods of $\mathrm{H}_{2} \mathrm{~S}$}

$\mathrm{H}_{2} \mathrm{~S}$ in aqueous solution can be found as hydrogen sulfide gas $\left(\mathrm{H}_{2} \mathrm{~S}\right)$ or in one of its dissociated forms, hydrosulfide anions $\left(\mathrm{HS}^{-}\right)$and sulfide anions $\left(\mathrm{S}^{2-}\right)$, although at physiological $\mathrm{pH}, \mathrm{S}^{2-}$ is only found in a negligible concentration. In addition, $\mathrm{H}_{2} \mathrm{~S}$ can bind to some biological matrixes (proteins, glutathione, etc.) and can dissociate in response to a physiological stimulus into free $\mathrm{H}_{2} \mathrm{~S}$. Moreover, the anion $\mathrm{HS}^{-}$and $\mathrm{H}_{2} \mathrm{~S}$ have a high propensity to oxidize, especially in the presence of trace metal ions and oxygen in water solutions [71]. Therefore, accurately and reliably measuring $\mathrm{H}_{2} \mathrm{~S}$ in vivo is an arduous task. Solutions should be prepared under a nitrogen or argon atmosphere, and $\mathrm{H}_{2} \mathrm{~S}$ volatilization should be prevented using septum-sealed vials. 
Methylene blue method: The first quantification method of $\mathrm{H}_{2} \mathrm{~S}$ was published in 1949 and included spectrophotometric determination using the methylene blue method, but the sensitivity was very low [72]. In 1969, an improved method was described based on the methylene blue method using n,n-dimethyl-p-phenylenediamine sulfate, which increased the sensitivity of the method by $10 \%$, with concentration limits of 1 to $1000 \mu \mathrm{M}$ [73]. However, the main drawbacks of this method for biological sample measurements are its low sensitivity, overestimation of $\mathrm{H}_{2} \mathrm{~S}$ under acidic $\mathrm{pH}$ and interference due to the turbidity of biological samples.

Monobromobimane derivatization (MBB): this is another method that is extensively used in biological samples to measure the $\mathrm{H}_{2} \mathrm{~S}$ concentration. In this method, $\mathrm{H}_{2} \mathrm{~S}$ is derivatized into a sulfide-dibimane product that can be subsequently measured by HPLC due to its fluorescence [74]. The sensitivity of MBB reaches the nanomolar range, but the weaknesses of this method are the instability of the standards and the need for exhaustive control of $\mathrm{pH}$ when comparing samples [75]. Another advantage of this method is that it allows the detection and quantification of all three sulfide biological forms: free hydrogen sulfide, acid-labile sulfide and bound sulfane sulfur [76]. An improved method based on MBB was developed that included ${ }^{36}$ S-labeled sulfide- dibimane as an internal standard and measured derivatized products by liquid chromatography-mass spectrometry [77]. This improvement ensured the sensitivity and feasibility of the method and also made it suitable for large-scale analysis.

The gas chromatography method was first used in 1988 [78] and was recently improved using a chemiluminescence sulfur detector to increase its sensitivity up to 0.5 pmol [79]. Nevertheless, the need for special equipment and special care in sample processing make this method not widely used.

Specific ion electrodes and polarographic sensors are others tools that have been used for $\mathrm{H}_{2} \mathrm{~S}$ quantitation. Their easy handling and the relatively inexpensive cost of electrodes make this method a good choice for several studies. Since this method does not require derivatization, it can be used for real-time measurements in biological samples. Nevertheless, it was reported that the sensitivity of this method is apparently affected by the materials used in the electrodes [75], and the main disadvantage of this method is the difficulty of calibration due to the formation of $\mathrm{Ag}_{2} \mathrm{~S}$ on the electrode surface.

$\mathbf{H}_{2}$ S-selective fluorescent probes are receiving increasing interest since they are powerful tools for the detection and quantification of $\mathrm{H}_{2} \mathrm{~S}$ in biological samples. Fluorescent probes have very high sensitivity and can be used for real-time measurements even in specific tissues or cellular compartments. The reactivity and specificity of these probes are based on the characteristic nucleophilicity of the anion $\mathrm{HS}^{-}$, on the reduction of an azide by $\mathrm{H}_{2} \mathrm{~S}$ into an amine compound, or on the quenching effect of $\mathrm{Cu}^{2+}$ of a nearby fluorophore and the strong affinity of anion sulfide for this heavy metal ion [80]. In addition, the increasing interest in other sulfane sulfur molecules, such as persulfides (R-S-SH), polysulfides $\left(\mathrm{R}-\mathrm{S}-\mathrm{S}_{\mathrm{x}}-\mathrm{S}-\mathrm{R}\right)$, and hydrogen polysulfides $\left(\mathrm{H}_{2} \mathrm{~S}_{\mathrm{x}}\right)$, in biological systems, has led to the development of probes that are able to detect these species. Several recent reviews summarize the latest probes reported in the literature [80,81]. However, the main limitation of these probes is the irreversible reaction that removes $\mathrm{H}_{2} \mathrm{~S}$ from the pool, leading to saturation [71]. Motivated by these limitations, Takano et al. designed a reversible fluorescent probe to detect these sulfane sulfur species, SSip-1, based on the ability of sulfane sulfur to bind other sulfur atoms [82]. In parallel, Dulac et al. developed a new method of reversible quantification in biological fluids, detecting up to $200 \mathrm{nM}^{\circ} \mathrm{H}_{2} \mathrm{~S}$ at $\mathrm{pH} 7.4$ using hemoglobin I from Lucina pectinate and a fluorophore [83]. Therefore, these reversible fluorescent probes allow the dynamics of intracellular sulfane sulfur molecules to be studied. Since the cytotoxicity of these probes is a drawback for their use in in vivo studies, a new low-cytotoxic biosensor for $\mathrm{H}_{2} \mathrm{~S}$ has recently been developed based on anthracene derivatives [84]. A further disadvantage in the plant system is the inability of these probes to penetrate the cell wall. Although there are few reports on the use of fluorescent probes for $\mathrm{H}_{2} \mathrm{~S}$ detection in plants, selective detection of intracellular $\mathrm{H}_{2} \mathrm{~S}$ was described using the probe WSP-1 [3'-methoxy-3-oxo-3H-spiro [isobenzofuran-1, 9'-xanthen]-6'-yl 2-(pyridin-2-yldisulfanyl) benzoate] in tomato roots [85]. However, the use of fluorescent probes for quantification of $\mathrm{H}_{2} \mathrm{~S}$ also has some limitations, such as a limited sensitivity range, interference by tissue autofluorescence when the emission/excitation wavelengths are similar, or non-specific reactions with 
other biological thiols. Thus, the fluorescent probe or the $\mathrm{H}_{2} \mathrm{~S}$ quantification method must be carefully chosen by the researcher depending on the sample, the tissue or organelle target, the sensitivity range, the equipment and the budget.

Data from in vivo measurements have been in conflict for a long time. The first data reported used the methylene blue method, and the $\mathrm{H}_{2} \mathrm{~S}$ concentration was above $35 \mu \mathrm{M}$ and from 50 to $160 \mu \mathrm{M}$ in mammalian plasma and brains, respectively $[86,87]$. However, these measurements were incorrect and using newly described methods, the $\mathrm{H}_{2} \mathrm{~S}$ concentration was more accurately reported at approximately $0.7-3 \mu \mathrm{M}$ in mammalian plasma [74]. Moreover, it has been recently reported than $\mathrm{H}_{2} \mathrm{~S}$ concentration in mouse plasma is about $15 \mathrm{nM}$ [88]. Taken altogether, the $\mathrm{H}_{2} \mathrm{~S}$ concentration has been estimated in the range of nanomolar, but the $\mathrm{H}_{2} \mathrm{~S}$ concentration may depend on the microenvironment at the precise moment of the $\mathrm{H}_{2} \mathrm{~S}$ measurement. For example, $\mathrm{H}_{2} \mathrm{~S}$ can be bound to sulfur compounds or conjugates and $\mathrm{H}_{2} \mathrm{~S}$ released under a certain stress or stimulus [89], $\mathrm{H}_{2} \mathrm{~S}$ biosynthesis may be up- or downregulated in particular scenarios [90,91], and $\mathrm{H}_{2} \mathrm{~S}$ consumption or accumulation may be modulated by the regulation of $\mathrm{H}_{2} \mathrm{~S}$ detoxification enzymes [92]. In addition, different $\mathrm{H}_{2} \mathrm{~S}$ concentrations have been reported in different tissues, species or stages of life. In cucurbit plants, the $\mathrm{H}_{2} \mathrm{~S}$ concentration was reported to be higher in leaves from older plants [93], while in Arabidopsis, the highest $\mathrm{H}_{2} \mathrm{~S}$ concentration was found in 2-week-old seedlings and gradually decreased in 4-10-week-old plants [94]. The highest $\mathrm{H}_{2} \mathrm{~S}$ content in Arabidopsis was found in flowers, while the lowest $\mathrm{H}_{2} \mathrm{~S}$ concentration was found in cauline leaves [94]. Determination of the $\mathrm{H}_{2} \mathrm{~S}$ concentration is further complicated by the fact that some stimuli only affect the $\mathrm{H}_{2} \mathrm{~S}$ concentration in some tissues, such as nicotine, which affects the $\mathrm{H}_{2} \mathrm{~S}$ concentration in the mouse kidney and heart but not in the brain and liver tissues [95]. A further important consideration must be taken when quantifying $\mathrm{H}_{2} \mathrm{~S}$ in biological samples, since $\mathrm{H}_{2} \mathrm{~S}$ is spontaneously oxidized in the presence of molecular $\mathrm{O}_{2}$ [96]. Therefore, the method of quantification must be accurate, and sample management must be taken into account because the $\mathrm{H}_{2} \mathrm{~S}$ concentration may not remain constant under certain conditions.

\section{4. $\mathrm{H}_{2} \mathrm{~S}$ Mechanism of Action}

The underlying mechanisms of $\mathrm{H}_{2} \mathrm{~S}$ action are poorly understood. There is an important effect of $\mathrm{H} 2 \mathrm{~S}$ binding to heme moieties in target proteins such as cytochrome c oxidase, hemoglobin and myoglobin, among others [97]. It has, however, become widely accepted that a huge number of the processes controlled by $\mathrm{H}_{2} \mathrm{~S}$ are caused by a posttranslational modification of cysteine residues called persulfidation [98-100]. Protein persulfidation is an oxidative posttranslational modification of cysteine residues caused by $\mathrm{H}_{2} \mathrm{~S}$, in which a thiol group (-SH) is transformed to a persulfide group (-SSH). Sulfane sulfur species, persulfides and polysulfides are more nucleophilic than $\mathrm{H}_{2} \mathrm{~S}$ and therefore more effective at persulfidation [101]. Due to the intrinsic instability of persulfides and their higher reactivity than thiols, protein persulfides largely remain understudied. Nevertheless, over the last decade, study of this protein modification has become more relevant for researchers because it can affect protein function, localization inside cells, stability, and resistance to oxidative stress [23,60,102-104]. The broad physiological importance of persulfidation has only recently started to emerge; a proteomic analysis revealed that approximately $10-25 \%$ of liver proteins contain this modification [104], and at least $5-10 \%$ of the entire proteome may undergo persulfidation in plants [105]. Several detection methods have been developed in recent years based on the nucleophilic characteristic of persulfide groups. Conversely, due to their instability and similarity to thiol groups, the development of a specific method for persulfide detection has become a challenge. These detection methods have recently been reviewed, including further explanations of the reactions and procedures [106-108]. Using these methods, researchers have been able to decipher the mechanism of action of $\mathrm{H}_{2} \mathrm{~S}$ through persulfidation in several diseases, such as cancer, neuronal degeneration diseases, or ischemia-reperfusion injury. Persulfidation of the $\alpha$ subunit of ATP synthase [109], lactate dehydrogenase A [110], the $\mathrm{K}_{\text {ATP }}$ channel [99,111], and MEK1 [112] contributes to cancer promotion. In Parkinson's disease patients, the E3 ubiquitin ligase PARKIN shows a decrease in persulfidation, which decreases its enzymatic activity [113]. Keap1 persulfidation protects 
gastric epithelial cells from ischemia/reperfusion injury [114]. In mammals, the mechanism of action of $\mathrm{H}_{2} \mathrm{~S}$ has been deeply studied since 2009, when Mustafa et al. described this new posttranslational modification [104]. By contrast, in the plant system, persulfidation has been described more recently [60], but a greater number of proteins have been shown to undergo this modification [105]. A total of 3147 proteins were found to be persulfidated in Arabidopsis leaves under physiological conditions, suggesting that this number may be higher under certain stress conditions [105]. These proteins are mainly involved in important biological pathways, such as the tricarboxylic acid cycle, glycolysis, Calvin cycle, photorespiration and autophagy. Further physiological studies of these proteins must be performed to decipher the role of persulfidation in these biological pathways. Nevertheless, initial studies in plants demonstrated that persulfidation regulates the enzymatic activity of chloroplastic glutamine synthetase (GS2), cytosolic ascorbate peroxidase (APX1), and cytosolic glyceraldehyde 3-phosphate dehydrogenase (GapC1) [60]. Persulfidation regulates the cytosolic/nuclear localization of GapC1, allowing it to likely act as a transcription factor [102]. The actin cytoskeleton and root hair growth are regulated through persulfidation of ACTIN2 [115]. Furthermore, ethylene biosynthesis is regulated by persulfidation of 1-aminocyclopropane-1-carboxylic acid oxidase (ACO1) in tomato [116]. Recently, a peroxisomal proteome study in Arabidopsis revealed that the interplay of different PTMs such as s-nitrosation, nitration, persulfidation, and acetylation regulates redox signaling to protect proteins against oxidative damage [117]. From an evolutionary point of view, it is reasonable to assume that ancestral purple and green sulfur bacteria lived in an $\mathrm{H}_{2} \mathrm{~S}$-rich atmosphere; and therefore bacteria developed $\mathrm{H}_{2} \mathrm{~S}$-mediated signaling processes to resist oxidative stress. Similarly as peroxide $\left(\mathrm{H}_{2} \mathrm{O}_{2}\right)$ produces ROS, persulfide $\left(\mathrm{H}_{2} \mathrm{~S}_{2}\right)$ produces RSS (reactive sulfide species), but with the difference that persulfides can be produced with several sulfur molecules $\left(\mathrm{S}_{\mathrm{x}}\right)$ and stored [118].

This assumption was described in a recent study, in which a proteomic evaluation of Staphylococcus aureus showed that many proteins regulated by persulfidation were involved in reactive oxygen and nitrogen species (ROS and RNS) stress-responses and that bacterial virulence was regulated by persulfidation of the HTH-type transcriptional regulator MgrA (MgrA), a global virulence regulator [119].

All these data suggest that persulfidation is a conserved mechanism of $\mathrm{H}_{2} \mathrm{~S}$ signaling throughout all kingdoms of life.

\section{Crosstalk of $\mathrm{H}_{2} \mathrm{~S}$ with Other Signaling Molecules}

\subsection{Nitric Oxide}

It is well established that $\mathrm{H}_{2} \mathrm{~S}$ regulates different physiological processes in cells directly or by crosstalk with other signaling molecules. There is clear evidence of crosstalk of $\mathrm{H}_{2} \mathrm{~S}$ and NO in the literature. In mammals, both gasotransmitters interact with each other to modulate the cardiovascular system by regulating angiogenesis and endothelium-dependent vasorelaxation $[120,121]$, and to modulate Alzheimer's disease by regulating pathways involved in the central nervous system [122]. Furthermore, inhibition of $\mathrm{NO}$ generation by $\mathrm{H}_{2} \mathrm{~S}$ has been extensively studied [123-125], but there is also evidence that NO can activate the production of $\mathrm{H}_{2} \mathrm{~S}$ in endothelial cells [126]. However, NO can bind to cystathionine $\beta$-synthase (CBS), which is responsible for $\mathrm{H}_{2} \mathrm{~S}$ biosynthesis and can impede its enzymatic activity [127], showing the complexity of the crosstalk between these two gasotransmitters.

In plants, $\mathrm{NO}$ and $\mathrm{H}_{2} \mathrm{~S}$ play crucial roles in the regulation of multiple responses towards a variety of abiotic and biotic stresses [44,128,129], including stomatal closure/aperture [46], modulation of photosynthesis $[34,130,131]$ and autophagy $[56,132,133]$. NO levels increase in plants under drought stress, which helps plants mitigate the negative effects of water deficit. NO increases the activities of antioxidant enzymes such as catalase (CAT), superoxide dismutase (SOD), ascorbate peroxidase (APX), glutathione reductase (GPX), and peroxidase (POD), and NO is an important player in ABA-induced stomatal closure, minimizing plant transpiration [134]. $\mathrm{H}_{2} \mathrm{~S}$ application reduces the accumulation of 
NO in guard cells, causing stomatal opening in the presence of light and preventing stomatal closure in the dark [45]. Exogenous $\mathrm{H}_{2} \mathrm{~S}$ induces stomatal closure through the regulation of ATP-binding cassette $(\mathrm{ABC})$ transporters, while scavenging $\mathrm{H}_{2} \mathrm{~S}$ can partially block $\mathrm{ABA}$-dependent stomatal closure, indicating the protective role of $\mathrm{H}_{2} \mathrm{~S}$ in plants against drought stress [46]. It has been demonstrated that $\mathrm{H}_{2} \mathrm{~S}$ acts downstream of $\mathrm{ABA}$ and upstream of $\mathrm{NO}$ [44]. $\mathrm{H}_{2} \mathrm{~S}$-induced stomatal closure can be reversed by $\mathrm{CPTIO}$ (a NO-specific scavenger), confirming that the function of $\mathrm{H}_{2} \mathrm{~S}$ in stomatal closure is mediated by $\mathrm{NO}$ [44]. It has been proposed that these contradictory effects of $\mathrm{H}_{2} \mathrm{~S}$ on stomatal movement and its crosstalk with NO depend on the environment or the age of the plant [135]. In agricultural crops such as pepper plants, the crosstalk between $\mathrm{NO}$ and $\mathrm{H}_{2} \mathrm{~S}$ plays an important role in the tolerance to iron deficiency and salt stress [136]; and these gasotransmitters partially modulate the NADPH-generating system by regulating 6-phosphogluconate dehydrogenase (6PGDH) and NADP-malic enzyme (NADP-ME) [137].

Furthermore, $\mathrm{NO}$ and $\mathrm{H}_{2} \mathrm{~S}$ are involved in the functional regulation of proteins, frequently with opposite effects. s-nitrosation of GAPC abolishes its catalytic activity, whereas persulfidation increases its activity $[60,138]$. Nonetheless, a cooperative effect of both signaling molecules can also be observed in the case of cytosolic ascorbate peroxidase (APX1), which can be S-nitrosylated by NO or persulfidated by $\mathrm{H}_{2} \mathrm{~S}$, both of which increase the activity of the enzyme. These reversible modifications may protect the enzyme from irreversible oxidation under abiotic stress, where the oxidative stress increases and s-nitrosothiols have usually been observed [139].

$\mathrm{H}_{2} \mathrm{~S}$ and NO may chemically interact and produce novel reactive molecules, such as nitroxyl (HNO) and nitrosothiols (RSNO) [140,141], which have their own outcomes. Recent studies also demonstrated that persulfides can produce $\mathrm{NO}$ using nitrite via intermediates such as polysulfide, $\mathrm{SNO}^{-}$(thionitrite) and $\mathrm{S}_{2} \mathrm{NO}^{-}$(perthionitrite, nitrosodisulfide) [142-144]. Therefore, $\mathrm{H}_{2} \mathrm{~S}$ and $\mathrm{NO}$ interaction forms some intermediates, which also have significant roles in cell signaling.

\subsection{Carbon Monoxide}

Carbon monoxide is another important gasotransmitter in animals; carbon monoxide is generated from oxidative degradation of heme by the enzyme heme oxygenase. CO may inhibit CBS activity and therefore may modulate $\mathrm{H}_{2} \mathrm{~S}$ biosynthesis [145]. Exogenous $\mathrm{H}_{2} \mathrm{~S}$ also upregulates the $\mathrm{CO} / \mathrm{heme}$ oxygenase system in the pulmonary arteries of hypoxic rats [146] and stimulates heme oxygenase levels in mouse retinal ganglion cells (RGC-5 cells) [147]. In plants, auxin induces endogenous $\mathrm{H}_{2} \mathrm{~S}$ and $\mathrm{CO}$ during the initiation of lateral root primordia, and this growth is promoted by $\mathrm{H}_{2} \mathrm{~S}$ but depends on the endogenous production of $\mathrm{CO}[50,148]$. Furthermore, in a similar way as in mammals, exogenous $\mathrm{H}_{2} \mathrm{~S}$ induces an increase in the transcription of heme oxygenase and its activity in tomato and cucumber roots $[149,150]$. Therefore, it has been suggested that $\mathrm{H}_{2} \mathrm{~S}$ regulates the feedback loop between the $\mathrm{CO} /$ heme oxygenase system and auxin during lateral root initiation [151]. Although the crosstalk between $\mathrm{H}_{2} \mathrm{~S}$ and $\mathrm{CO}$ needs further study, previous research on plant and animal systems provides evidence for an interrelationship of these two signaling molecules.

\subsection{Hydrogen Peroxide}

Hydrogen peroxide $\left(\mathrm{H}_{2} \mathrm{O}_{2}\right)$ is a well-known signaling molecule in plants. $\mathrm{H}_{2} \mathrm{O}_{2}$ emerged as a key signaling molecule that enhances abiotic stress resistance by modulating the expression of resistance genes and antioxidant enzyme activities. Recently, signaling crosstalk between $\mathrm{NO}$ and $\mathrm{H}_{2} \mathrm{~S}$ with $\mathrm{H}_{2} \mathrm{O}_{2}$ has been shown to induce thermotolerance in maize seedlings [152]. Hydrogen peroxide is also involved in $\mathrm{H}_{2} \mathrm{~S}$-induced lateral root formation in tomato seedlings, revealing that the cell cycle regulatory genes modulated by $\mathrm{H}_{2} \mathrm{~S}$, such as up-regulation of SlCYCA2;1, SlCYCA3;1, and SICDKA1, and down-regulation of $S I K R P 2$, are prevented by co-treatment with $\mathrm{H}_{2} \mathrm{O}_{2}$ scavengers [153]. A study in Vicia faba revealed crosstalk between $\mathrm{H}_{2} \mathrm{~S}$ and $\mathrm{H}_{2} \mathrm{O}_{2}$ in salt stress-induced stomatal closure, with $\mathrm{H}_{2} \mathrm{~S}$ being downstream of $\mathrm{H}_{2} \mathrm{O}_{2}$ [154]. This observation was also described in white clover, where $\mathrm{H}_{2} \mathrm{~S}$ acts as a downstream signal of $\mathrm{H}_{2} \mathrm{O}_{2}$ and $\mathrm{NO}$ in response to dehydration [155]. A recent study showed 
a newly discovered crosstalk between $\mathrm{H}_{2} \mathrm{~S}$ and $\mathrm{H}_{2} \mathrm{O}_{2}$ in another abiotic stress response, in which $\mathrm{H}_{2} \mathrm{~S}$ can act as a positive regulator of Vacuolar $\mathrm{H}+$-ATPase, while $\mathrm{H}_{2} \mathrm{O}_{2}$ acts as a negative regulator during cadmium stress in cucumber roots [156]. In mammalian cells, $\mathrm{H}_{2} \mathrm{O}_{2}$ is a key signal in redox regulation, and as it occurs in plants, these regulatory pathways may also be influenced by $\mathrm{H}_{2} \mathrm{~S}_{2} \mathrm{H}_{2} \mathrm{O}_{2}$ is produced by NAPDH oxidases in the plasma membrane and is transported to the cytosol through protein channels named aquaporins (AQP3, AQP8, and AQP9). It has been demonstrated that treatment with $\mathrm{H}_{2} \mathrm{~S}$ is sufficient to block $\mathrm{H}_{2} \mathrm{O}_{2}$ cell permeability in unstressed cells, and this phenomenon is mediated by the persulfidation of cysteine 53 of AQP8 [157]. By contrast, $\mathrm{H}_{2} \mathrm{~S}$ production is dependent on the levels of $\mathrm{H}_{2} \mathrm{O}_{2}$ produced by NADPH oxidase, which attenuates the phosphorylation of vascular endothelial growth factor receptor 2 (VEGFR2) [158]. As with NO and CO, autoregulation of these signals may be influenced by their generation, increasing or reducing their intracellular concentrations depending on the levels of each other. Another example was provided by Feng et al., who found that autophagy was induced by $\mathrm{H}_{2} \mathrm{O}_{2}$ through ER stress in cardiac fibroblast cells and that $\mathrm{H}_{2} \mathrm{~S}$ was able to suppress autophagic flux by inhibiting ROS production and preserving mitochondrial function [159]. All these studies establish a link for $\mathrm{H}_{2} \mathrm{~S} / \mathrm{H}_{2} \mathrm{O}_{2}$ crosstalk.

\subsection{Hormones}

$\mathrm{H}_{2} \mathrm{~S}$ is a regulator of glucose homeostasis and plays an important role in the metabolism of hormones, such as insulin and glucagon [160,161]. It has been demonstrated that $\beta$ cells of the pancreas can produce high levels of $\mathrm{H}_{2} \mathrm{~S}$, predominantly by cystathionine $\gamma$-lyase (CSE), which blocks glucose-stimulated insulin secretion [162]. This effect is caused by increased endoplasmic reticulum stress, leading to apoptosis of $\beta$ cells, which drives the reduction in insulin secretion [161]. Some other studies revealed the importance of $\mathrm{H}_{2} \mathrm{~S}$ in the modulation of estrogen receptor expression and its anti-proliferative effect on vascular smooth muscle cell growth and proliferation [163]. Further research concluded that the antiatherosclerotic effect of estrogen is mediated by CSE-generated $\mathrm{H}_{2} \mathrm{~S}$ and that $\mathrm{H}_{2} \mathrm{~S}$ production in the liver and vascular tissues is enhanced by estrogen via its stimulatory effect on CSE activity [164]. In a recent study, $\mathrm{H}_{2} \mathrm{~S}$ signaling was also linked with the regulation of two endocrine hormones associated with longevity control, growth hormone and thyroid hormone. Thyroid hormone suppresses $\mathrm{H}_{2} \mathrm{~S}$ production by inhibiting CSE gene expression, while growth hormone controls its substrate availability via autophagy. Surprisingly, CSE-generated $\mathrm{H}_{2} \mathrm{~S}$ is necessary for the feedback regulation of thyroid and growth hormones [165].

Moreover, $\mathrm{H}_{2} \mathrm{~S}$ has been linked to plant hormone signaling, such as gibberellin (GA) [166], auxin [33], jasmonic acid (JA) [167], ethylene (ET) [168], salicylic acid (SA) [169] and abscisic acid (ABA) [45-47].

A synergistic effect between GA and $\mathrm{H}_{2} \mathrm{~S}$ was observed in seed germination in plants, and this outcome was more evident when treatment with $\mathrm{H}_{2} \mathrm{~S}$ was prolonged [170]. It was also observed that GA decreased L-cysteine desulfhydrase (LCD) activity and thus $\mathrm{H}_{2} \mathrm{~S}$ production. This enzyme inhibition induced an increase in programmed cell death (PCD) [166]. Nevertheless, exogenous $\mathrm{H}_{2} \mathrm{~S}$ treatment alleviated GA-triggered PCD in wheat aleurone cells and blocked the decrease in endogenous $\mathrm{H}_{2} \mathrm{~S}$ release by modulating glutathione homeostasis and heme oxygenase-1 gene expression [166].

Auxin is a phytohormone associated with lateral root morphogenesis and root growth regulation. Similar to other phytohormones, a synergistic effect with $\mathrm{H}_{2} \mathrm{~S}$ has been observed. Exogenous treatments with $\mathrm{H}_{2} \mathrm{~S}$ donors increased the number and length of lateral roots in sweet potato seedlings in a dose-dependent manner [33]. As mentioned previously in this review, crosstalk between the $\mathrm{CO} /$ heme oxygenase system and $\mathrm{H}_{2} \mathrm{~S}$ is established during lateral root initiation [151]. Furthermore, $\mathrm{H}_{2} \mathrm{~S}$ can modulate $C D K A ; 1, C Y C A 2 ; 1$ and Cyclin-dependent kinase inhibitor 2 (KRP2) gene expression and act as a downstream component of auxin signaling to activate lateral root formation in tomato [50]. New data shed light on this crosstalk recently, as it was reported that $\mathrm{H}_{2} \mathrm{~S}$ inhibited auxin transport through modulation of the subcellular distribution of Peptidyl-prolyl cis-trans isomerase NIMA-interacting (PIN) proteins [171], which is an actin-dependent process. Additionally, it was 
proven that the regulation of the F-actin cytoskeleton in Arabidopsis roots by $\mathrm{H}_{2} \mathrm{~S}$ could affect the auxin distribution in plants [171]. Therefore, the signaling network that includes auxin, $\mathrm{H}_{2} \mathrm{~S}$ and F-actin must be finely knotted to regulate root development.

Jasmonic acid regulates diverse plant growth processes and is involved in defense responses against biotic and abiotic stresses. It is well known that $\mathrm{H}_{2} \mathrm{~S}$ can regulate abiotic stress tolerance and biotic stress resistance in Arabidopsis [172] and that $\mathrm{H}_{2} \mathrm{~S}$ is involved in JA-induced stomatal closure [173]. However, the interaction between $\mathrm{H}_{2} \mathrm{~S}$ and JA is still under study. A recent publication demonstrated that treatment with JA promoted endogenous $\mathrm{H}_{2} \mathrm{~S}$ generation and that treatments with exogenous $\mathrm{H}_{2} \mathrm{~S}$ donors significantly enhanced JA-induced cadmium tolerance [167]. This observation was also described by other authors, whose research described that JA treatments increased D-cysteine desulfhydrase activity and that this JA-induced $\mathrm{H}_{2} \mathrm{~S}$ regulated ascorbate and glutathione metabolism [61]. Taken together, these data suggest intertwined signaling between $\mathrm{H}_{2} \mathrm{~S}$ and this plant hormone.

Salicylic acid is a phenolic compound involved in local and systemic plant defense responses against pathogens and abiotic stress. SA treatment increased the activity of L-cysteine desulfhydrase and $\mathrm{H}_{2} \mathrm{~S}$ accumulation, which improved the heat tolerance of maize seedlings [174]. Contrary to the feedback observed for other hormones and $\mathrm{H}_{2} \mathrm{~S}$, sulfide treatments had no significant effect on SA accumulation and its biosynthesis enzymes [169]. However, a synergistic role was observed between $\mathrm{SA}$ and $\mathrm{H}_{2} \mathrm{~S}$ in the antioxidant system and osmolyte in crosstalk-induced heat tolerance of maize seedlings [169].

ET is another phytohormone that has been linked with $\mathrm{H}_{2} \mathrm{~S}$ signaling. Several authors have described how exogenous treatments with ET induce L- and D-cysteine desulfhydrase activity, and this $\mathrm{H}_{2} \mathrm{~S}$ regulates ethylene-induced stomatal closure in Arabidopsis thaliana and Vicia faba $[168,175,176]$. A new study revealed that treatments with ET induced $\mathrm{H}_{2} \mathrm{~S}$ generation, and feedback regulation was also observed since ethylene-induced $\mathrm{H}_{2} \mathrm{~S}$ negatively regulated ethylene biosynthesis; this regulation occurred through the persulfidation of ACO1 in tomato plants [116]. Further investigations have shown that $\mathrm{H}_{2} \mathrm{~S}$ may have an antagonistic effect on ethylene, reducing oxidative stress and repressing ethylene synthesis-related gene expression [177].

In recent years, the crosstalk of $\mathrm{ABA}$ with $\mathrm{H}_{2} \mathrm{~S}$ has been the focus of several investigations since ABA is a key player in plant physiology, mainly under drought stress. It has been broadly reported that $\mathrm{H}_{2} \mathrm{~S}$ plays a role in stomatal closure $[43,46]$ and that impaired $\mathrm{H}_{2} \mathrm{~S}$ generation mutants $(D E S 1$ knockout Arabidopsis mutants) do not show stomatal closure upon ABA treatment, although this effect could be reversed by exogenous application of $\mathrm{H}_{2} \mathrm{~S}$ [46]. This crosstalk was also observed in wheat [178]. Surprisingly, abi1 mutants were not able to close their stomata in response to sulfide, suggesting that functional ABI1 is required to close the stomata through $\mathrm{H}_{2} \mathrm{~S}$ [44]. As described above, $\mathrm{H}_{2} \mathrm{~S}$ acts upstream of $\mathrm{NO}$ to regulate ABA-induced stomatal closure [44], but $\mathrm{H}_{2} \mathrm{~S}$ acts downstream of $\mathrm{NO}$ in ethylene-induced stomatal closure [175]. In a parallel study, the authors demonstrated that $\mathrm{H}_{2} \mathrm{~S}$ induced ABA-dependent stomatal opening instead [45], which was further demonstrated by Honda et al., who found that $\mathrm{H}_{2} \mathrm{~S}$ donors were able to close the stomata during the first 150 min of treatment and induce opening after prolonged treatments [179]. This dual effect could be related to the production of $\mathrm{NO}$ in guard cells, and therefore, a complex crosstalk of $\mathrm{H}_{2} \mathrm{~S}, \mathrm{NO}$, ET and ABA might regulate stomatal movement depending on environmental stress. A recent study demonstrated the persulfidation of several proteins involved in ABA signaling and ABA biosynthesis, such as SnRK2.2, a key component and activator of ABA signaling; two ABA receptors, pyrabactin resistance receptor 1 (PYR1) and pyrabactin resistance-like receptor (PYL1); the protein phosphatase 2C (HAB2), which is a repressor of ABA signaling; and the nuclear transcription factor Y (NFYC4), which is involved in the ABA signaling pathway [105]. Another enzyme that was shown to be persulfidated in this study was phospholipase $\mathrm{D}$, the activity of which was demonstrated to be regulated by $\mathrm{H}_{2} \mathrm{~S}$ to control stomatal closure [180]. Other studies demonstrated the s-nitrosation of some proteins involved in ABA signaling, such as the leucine zipper transcription factor Abscisic acid insensitive 5 (ABI5); SnRK2.2, which was also 
persulfidated; and Open Stomata1 (OST1) [181,182]. The mechanism of action of $\mathrm{H}_{2} \mathrm{~S}$ and $\mathrm{NO}$ in this tight regulation has been proposed to be through persulfidation and s-nitrosation of proteins that play key roles in ABA signaling [105,182]. More recently, the mechanism of action of this crosstalk was deciphered; ABA stimulates the persulfidation of L-cysteine desulfhydrase 1, and $\mathrm{H}_{2} \mathrm{~S}$ accumulation drives persulfidation of the NADPH oxidase respiratory burst oxidase homolog protein D (RBOHD), enhancing its activity and triggering stomatal closure [183].

\subsection{Thioredoxins}

As proposed by several authors, one mechanism of action of $\mathrm{H}_{2} \mathrm{~S}$ is modulation of protein persulfidation, but the thiol group may undergo a wide range of posttranslational modifications (PTMs) in cells, including oxidation to disulfide (-S-S-), sulfenylation (-SOH), sulfinylation $\left(-\mathrm{SO}_{2} \mathrm{H}\right)$, and sulfonylation $\left(-\mathrm{SO}_{3} \mathrm{H}\right)$; s-nitrosation (-SNO) and glutathionylation (-SS-glutathione). Some of these PTMs can be chemically reversible by reductants in vivo, such as glutathione, or by a cysteine nucleophilic attack to rebuild a disulfide bond. Thioredoxins (TRX) are small oxidoreductases that mainly reduce oxidized cysteines and cleave disulfide bonds. However, TRX may also act as transpersulfidases [184], denitrosylases [185,186] or deglutathionylases [187]. Hence, modified cysteines can be restored to a thiol group. In that sense, persulfidation may protect cysteine residues from the other oxidative modifications, which can be eventually more damaging or irreversible. Deregulation of $\mathrm{H}_{2} \mathrm{~S}, \mathrm{NO}$ or glutathione levels in the cell can be devastating, and these signaling molecules can reversibly modify proteins. Thioredoxin could be necessary to restore a native protein and transfer the modification to another protein to fulfil other outcomes.

In a prolonged oxidative environment, thiol oxidation leads to the irreversible formation of sulfinic and sulfonic acids. $\mathrm{H}_{2} \mathrm{~S}$ has been proposed to act as a protective molecule to avoid these irreversible modifications, since persulfidated proteins can react with reactive oxygen/nitrogen species but can also be reduced by thioredoxins to restore the thiol group [108]. The role of thioredoxins in maintaining persulfidation has been reported in human embryonic kidney cells and the mouse liver because two thioredoxin knockdown cells showed increased polysulfide and protein persulfidation levels [188]. In a recent study, it has been demonstrated that $\mathrm{H}_{2} \mathrm{~S}$ regulates the redox state of $\operatorname{Tr}$, disrupting the $\mathrm{H}_{2} \mathrm{O}_{2}$-initiated polymerization of Trx, modulating this antioxidant system [189]

The interaction between $\mathrm{H}_{2} \mathrm{~S}$ and a wide number of other signaling molecules indicates that $\mathrm{H}_{2} \mathrm{~S}$ is an essential molecule of signaling in cell life (Figure 2).

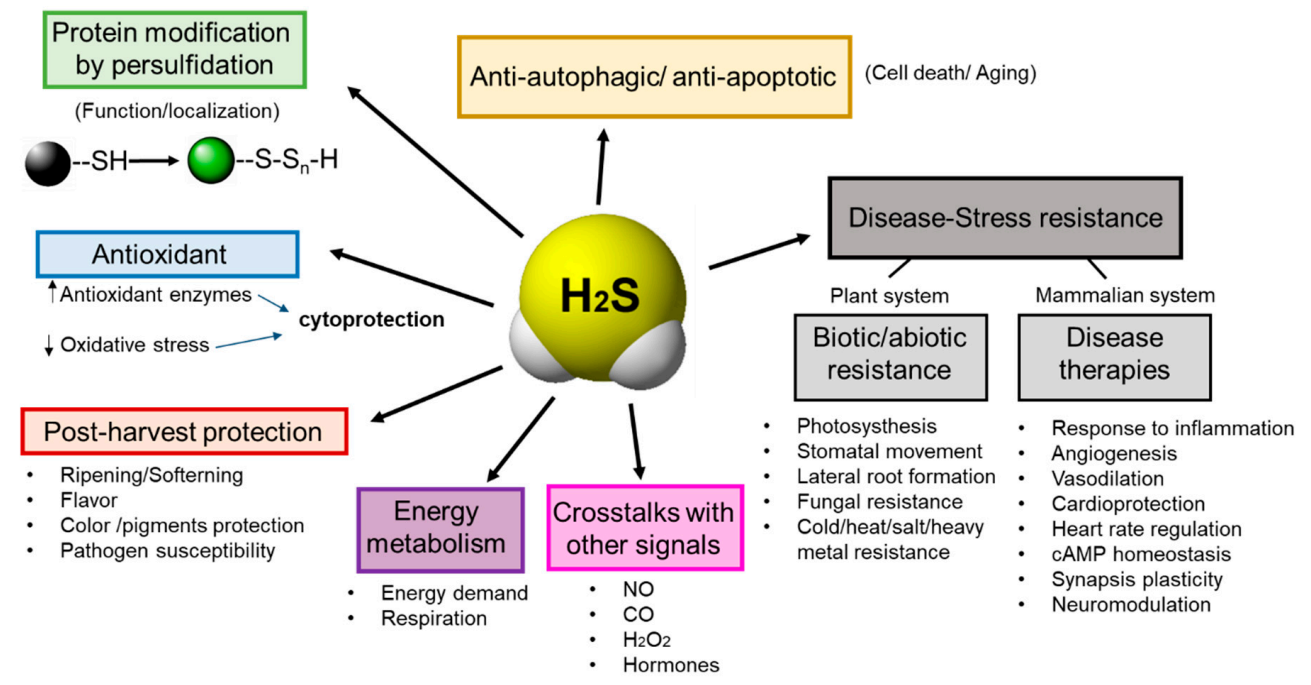

Figure 2. $\mathrm{H}_{2} \mathrm{~S}$ is a key activator of multiple physiological processes. $\mathrm{H}_{2} \mathrm{~S}$-mediated signaling ranges from protein modification by persulfidation to affecting a broad range of physiological processes, including regulation of oxidative stress, postharvest protection, disease resistance, autophagy signaling, energy metabolism regulation and crosstalk with other signaling molecules. 


\section{6. $\mathrm{H}_{2} \mathrm{~S}$ in Human and Plant Therapies}

It is well known that sulfurous water baths were used by ancient civilizations and were known to have healing effects against particular diseases. $\mathrm{H}_{2} \mathrm{~S}$ has been recognized as having anti-inflammatory, anti-bacterial, vasodilator, and anti-fungal properties owing to its sulfur content [68,190,191]. Several extracts from the genus Allium, mainly onion and garlic, and their derivatives have been used since ancient times in China as medicines to treat numerous diseases, including cancer [192], cardiovascular disease [193] and other diseases. It is known that these extracts are a source of sulfur-containing flavor compounds such as diallyl sulfide, allicin and cycloalliin, among others, and which release $\mathrm{H}_{2} \mathrm{~S}$ in cells upon interaction with reductants [194,195].

Currently, these beneficial effects are still under study to develop new strategies and therapies to treat certain diseases in mammals and to address agricultural challenges. In mammals, therapies that include $\mathrm{H}_{2} \mathrm{~S}$ are used for their anti-inflammatory effects, cytoprotective properties and antiapoptotic features [196]. The aim of these therapies is to be able to use this signaling molecule in heart failure, neurodegenerative diseases and stroke, and ischemia, among others. There has recently been an increasing number of publications indicating that deficiency or excess sulfur amino acids (SAAs), namely, methionine and cysteine, in the diet affect the normal growth of animals and that it is important that SAAs are ingested at the appropriate dose $[197,198]$, since they affect signaling in cells through $\mathrm{H}_{2} \mathrm{~S}$ [199]. These amino acids are metabolized through the transsulfuration pathway, which is the one of the main sources of $\mathrm{H}_{2} \mathrm{~S}$ in cells; $\mathrm{H}_{2} \mathrm{~S}$ has been shown to increase the lifespan of C. elegans [200] and even humans [201].

Nevertheless, clinical research on $\mathrm{H}_{2} \mathrm{~S}$ is not easy to perform due to its toxicity, and $\mathrm{H}_{2} \mathrm{~S}$ therapy is still in a preliminary preclinical stage. A bottleneck for developing gasotransmitter-based therapeutics is the lack of a safe administration drug. There are some candidate compounds for $\mathrm{CO}$ and NO prodrugs [202-204] and more interestingly, some $\mathrm{H}_{2} \mathrm{~S}$-releasing drugs are currently in clinical trials $[205,206]$. In a recent study, intraperitoneal injections of JK-1 (a $\mathrm{H}_{2} \mathrm{~S}$ donor) were administered to mice after transverse aortic constriction and were shown to have substantial beneficial effects on renal and vascular function [207]. Another exciting approach was a high increase in the dietary intake of taurine, which boosted CSE-mediated $\mathrm{H}_{2} \mathrm{~S}$ production to exert significant protective effects in atherogenesis, hypertension and heart failure [208]. However, most therapies use an increase in the dietary intake of sulfur amino acids or directly use slow-releasing $\mathrm{H}_{2} \mathrm{~S}$ donors to avoid the toxicity of high $\mathrm{H}_{2} \mathrm{~S}$ concentrations [209]. These therapies in mouse models can be used as models to study $\mathrm{H}_{2} \mathrm{~S}$ donors in humans. A recent study revealed that persulfidation decreases with aging and that dietary/pharmacological interventions could be used to increase persulfidation and extend lifespan [210]. Moreover, a few recently published articles described the interplay between $\mathrm{H}_{2} \mathrm{~S}, \mathrm{CO}$ and $\mathrm{NO}$ within the gastrointestinal tract, especially in ulcer healing and prevention of non-steroidal anti-inflammatory drugs (NSAIDs) - induced gastropathy [211,212]. In addition, a novel $\mathrm{H}_{2} \mathrm{~S}$ donor not only increases $\mathrm{H}_{2} \mathrm{~S}$ levels, but also increases circulating $\mathrm{NO}$ bioavailability in heart failure patients, highlighting the crosstalk between these gasotransmitters in therapeutic trials [213].

In plants, new therapies or strategies using $\mathrm{H}_{2} \mathrm{~S}$ are being used to deal with economic losses due to fruit and vegetable ripening or crop stress resistance. It has been shown that $\mathrm{H}_{2} \mathrm{~S}$ fumigation slows fruit ripening and senescence in fruits and vegetables by inducing antioxidant activities, such as ascorbate peroxidase, catalase, peroxidase, glutathione reductase, and superoxide dismutase [214216]. Treatments with exogenous $\mathrm{H}_{2} \mathrm{~S}$ have also been used to control the color degradation of certain horticultural vegetables and fruits by suppressing the degradation of anthocyanins [214] and downregulating some chlorophyll degradation genes [217]. Interactions between $\mathrm{H}_{2} \mathrm{~S}$ and other signaling molecules, such as NO and ethylene, have also been a focus of recent investigations on the senescence of flowers or ripening of fruits. Hydrogen sulfide alleviates postharvest ripening and senescence of fruits by antagonizing the effect of ethylene [218,219]. In addition, a cooperative effect of $\mathrm{H}_{2} \mathrm{~S}$ and NO has been observed on delaying the softening and decay of fruits [220], and the crosstalk between these two gasotransmitters is associated with the inhibition of ethylene biosynthesis [221]. 
There is a long list of publications on the beneficial effects of $\mathrm{H}_{2} \mathrm{~S}$ treatments in crops, such as enhancing resistance to metal, heat, cold, salt and drought stresses, which have been recently summarized [222]. It has been demonstrated that sulfur fertilization of crops reduces sensitivity to pathogens, in a process mediated by hydrogen sulfide [16]. $\mathrm{H}_{2} \mathrm{~S}$-induced pathogen resistance is conferred through increased expression of salicylic acid-dependent pathogen-related (PR) genes [223] and increased transcription levels of microRNA393 (MIR393) genes [39]. Another important beneficial effect of $\mathrm{H}_{2} \mathrm{~S}$ treatment of crops is its influence on the modulation of photosynthesis [34] and autophagy regulation [57]. Apparently, $\mathrm{H}_{2} \mathrm{~S}$ is able to regulate energy production in mitochondria, protecting against aging and increasing the lifespan of plants in a similar way as in animals [224]. All of these advantageous outcomes lead to increased yields and biomass and enhanced germination of agricultural crops after $\mathrm{H}_{2} \mathrm{~S}$ administration [48,225].

\section{Conclusions and Future Research}

Early life forms had to survive in an atmosphere that contained highly reactive compounds, such as $\mathrm{NO}, \mathrm{CO}$ and $\mathrm{H}_{2} \mathrm{~S}$, and it seems that during evolution, early life forms not only tolerated these compounds but also included them as important molecules in their signaling mechanisms.

In this review, we summarized the wide promiscuity of $\mathrm{H}_{2} \mathrm{~S}$, which is able to react with a broad range of signaling molecules, acting on its own or in cooperation with those molecules. In addition, we showed that a wide series of pathways are regulated by $\mathrm{H}_{2} \mathrm{~S}$, including either important physiological pathways and pathophysiological or stress conditions. Persulfidation has been proposed to be the mechanism of action of $\mathrm{H}_{2} \mathrm{~S}$ in cells throughout all regna, but how this modification affects individual proteins and the general consequences on signaling pathways needs further study. The instability of $\mathrm{H}_{2} \mathrm{~S}$ and persulfidated cysteines and the imprecise quantitative detection methods for them have slowed the progress of research. Further investigation into developing an appropriate detection method is crucial to understanding $\mathrm{H}_{2} \mathrm{~S}$ signaling. Future studies on the compartmentalization or microenvironment of these molecules will be important for studying different modifications on the same target and their biological outcomes. A better understanding of this signaling pathway would shed light on new targets for medical therapies and agricultural remedies.

Author Contributions: A.A. organized, wrote and prepared the manuscript. C.G., D.C.B. and L.C.R. contributed to writing and reviewing the major parts of the manuscript. All authors have read and agreed to the published version of the manuscript.

Funding: This work has received funding from the European Union's Horizon 2020 research and innovation programme under the Marie Skłodowska-Curie grant agreement No. 834120.

Acknowledgments: We thank Marie Skłodowska-Curie grant agreement No. 834120 for funding support and Junta de Andalucia-FEDER (Project ref. US-1255781).

Conflicts of Interest: The authors declare that this research was conducted in the absence of any commercial or financial relationships that could be construed as potential conflicts of interest.

\section{References}

1. Reiffenstein, R.J.; Hulbert, W.C.; Roth, S.H. Toxicology of hydrogen sulfide. Annu. Rev. Pharmacol. Toxicol. 1992, 32, 109-134. [CrossRef] [PubMed]

2. Chaussier, F. Précis d'experiences faites sur les animaux avec le gaz hydrogéne sulfuré. J. Gen. Med. Chir. Pharm 1908, 15, 19-39.

3. Nicholls, P. Inhibition of Cytochrome c Oxidase by Sulphide. Biochem. Soc. Trans. 1975, 3, 316-319. [CrossRef] [PubMed]

4. Willis, C.L.; Gibson, G.R.; Holt, J.; Allison, C. Negative correlation between oral malodour and numbers and activities of sulphate-reducing bacteria in the human mouth. Arch. Oral Biol. 1999, 44, 665-670. [CrossRef]

5. Suarez, F.; Furne, J.; Springfield, J.; Levitt, M. Insights into human colonic physiology obtained from the study of flatus composition. Am. J. Physiol. 1997, 272, G1028-G1033. [CrossRef] [PubMed] 
6. Stipanuk, M.H.; Beck, P.W. Characterization of the enzymic capacity for cysteine desulphhydration in liver and kidney of the rat. Biochem. J. 1982, 206, 267-277. [CrossRef]

7. Kuo, S.M.; Lea, T.C.; Stipanuk, M.H. Developmental Pattern, Tissue Distribution, and Subcellular Distribution of Cysteine: $\alpha$-Ketoglutarate Aminotransferase and 3-Mercaptopyruvate Sulfurtransferase Activities in the Rat. Neonatology 1983, 43, 23-32. [CrossRef]

8. Wang, J.; Guo, X.; Li, H.; Qi, H.; Qian, J.; Yan, S.; Shi, J.; Niu, W. Hydrogen Sulfide From Cysteine Desulfurase, Not 3-Mercaptopyruvate Sulfurtransferase, Contributes to Sustaining Cell Growth and Bioenergetics in E. coli Under Anaerobic Conditions. Front. Microbiol. 2019, 10, 2357. [CrossRef]

9. Modis, K.; Wolanska, K.; Vozdek, R. Hydrogen sulfide in cell signaling, signal transduction, cellular bioenergetics and physiology in C. elegans. Gen. Physiol. Biophys. 2013, 32, 1-22. [CrossRef]

10. Seiflein, T.A.; Lawrence, J.G. Two Transsulfurylation Pathways in Klebsiella pneumoniae. J. Bacteriol. 2006, 188, 5762-5774. [CrossRef]

11. Mironov, A.; Seregina, T.; Nagornykh, M.; Luhachack, L.G.; Korolkova, N.; Lopes, L.E.; Kotova, V.; Zavilgelsky, G.; Shakulov, R.; Shatalin, K.; et al. Mechanism of H2S-mediated protection against oxidative stress in Escherichia coli. Proc. Natl. Acad. Sci. USA 2017, 114, 6022-6027. [CrossRef] [PubMed]

12. Saghir, A.R.; Mann, L.K.; Bernhard, R.A.; Jacobsen, J.V. Determination of aliphatic mono- and disulfides in Allium by gas chromatography and their distribution in the common food species. Proc. Am. Soc. Hort. Sci. 1964, 84, 386-398.

13. De Cormis, L. Release of hydrogen sulfide into an atmosphere containing sulfur dioxide. CR Acad. Sci. 1968, 266, 683-685.

14. Rennenberg, H.; Arabatzis, N.; Grundel, I. Cysteine desulphydrase activity in higher plants: Evidence for the action of L- and D-cysteine specific enzymes. Phytochemistry 1987, 26, 1583-1589. [CrossRef]

15. Riemenschneider, A.; Wegele, R.; Schmidt, A.; Papenbrock, J. Isolation and characterization of a D-cysteine desulfhydrase protein from Arabidopsis thaliana. FEBS J. 2005, 272, 1291-1304. [CrossRef]

16. Bloem, E.; Riemenschneider, A.; Volker, J.; Papenbrock, J.; Schmidt, A.; Salac, I.; Haneklaus, S.; Schnug, E. Sulphur supply and infection with Pyrenopeziza brassicae influence L-cysteine desulphydrase activity in Brassica napus L. J. Exp. Bot. 2004, 55, 2305-2312. [CrossRef]

17. Kimura, J. Message from the editor's office. Muscle Nerve 1990, 13, 1095. [CrossRef]

18. Abe, K.; Kimura, H. The possible role of hydrogen sulfide as an endogenous neuromodulator. J. Neurosci. Off. J. Soc. Neurosci. 1996, 16, 1066-1071. [CrossRef]

19. Wang, R. Gasotransmitters: Growing pains and joys. Trends Biochem. Sci. 2014, 39, 227-232. [CrossRef]

20. Olas, B. Hydrogen sulfide in signaling pathways. Clin. Chim. Acta Int. J. Clin. Chem. 2015, 439, $212-218$. [CrossRef]

21. Paul, B.D.; Snyder, S.H. Modes of physiologic H2S signaling in the brain and peripheral tissues. Antioxid. Redox Signal. 2015, 22, 411-423. [CrossRef] [PubMed]

22. Martelli, A.; Testai, L.; Breschi, M.C.; Blandizzi, C.; Virdis, A.; Taddei, S.; Calderone, V. Hydrogen sulphide: Novel opportunity for drug discovery. Med. Res. Rev. 2012, 32, 1093-1130. [CrossRef]

23. Paul, B.D.; Snyder, S.H. H2S signalling through protein sulfhydration and beyond. Nat. Rev. Mol. Cell Biol. 2012, 13, 499-507. [CrossRef] [PubMed]

24. Panthi, S.; Manandhar, S.; Gautam, K. Hydrogen sulfide, nitric oxide, and neurodegenerative disorders. Transl. Neurodegener. 2018, 7, 3. [CrossRef] [PubMed]

25. Giuliani, D.; Ottani, A.; Zaffe, D.; Galantucci, M.; Strinati, F.; Lodi, R.; Guarini, S. Hydrogen Sulfide Slows down Progression of Experimental Alzheimer's Disease by Targeting Multiple Pathophysiological Mechanisms. Neurobiol. Learn. Mem. 2013, 104, 82. [CrossRef] [PubMed]

26. Cao, X.; Cao, L.; Ding, L.; Bian, J.S. A New Hope for a Devastating Disease: Hydrogen Sulfide in Parkinson's Disease. Mol. Neurobiol. 2018, 55, 3789-3799. [CrossRef] [PubMed]

27. Paul, B.D.; Sbodio, J.I.; Xu, R.; Vandiver, M.S.; Cha, J.Y.; Snowman, A.M.; Snyder, S.H. Cystathionine $\gamma$-Lyase Deficiency Mediates Neurodegeneration in Huntington's Disease. Nature 2014, 509, 96. [CrossRef]

28. Hellmich, M.R.; Szabo, C. Hydrogen Sulfide and Cancer. Handb. Exp. Pharmacol. 2015, 230, 233.

29. Wu, D.; Si, W.; Wang, M.; Lv, S.; Ji, A.; Li, Y. Hydrogen Sulfide in Cancer: Friend or Foe? Nitric Oxide Biol. Chem./Off. J. Nitric Oxide Soc. 2015, 50, 38. [CrossRef]

30. Wu, D.; Wang, H.; Teng, T.; Duan, S.; Ji, A.; Li, Y. Hydrogen sulfide and autophagy: A double edged sword. Pharmacol. Res. 2018, 131, 120-127. [CrossRef] 
31. Rodriguez-Kabana, R.; Jordan, J.W.; Hollis, J.P. Nematodes: Biological Control in Rice Fields: Role of Hydrogen Sulfide. Science 1965, 148, 524-526. [CrossRef] [PubMed]

32. Zhang, H.; Hu, L.Y.; Hu, K.D.; He, Y.D.; Wang, S.H.; Luo, J.P. Hydrogen sulfide promotes wheat seed germination and alleviates oxidative damage against copper stress. J. Integr. Plant Biol. 2008, 50, 1518-1529. [CrossRef] [PubMed]

33. Zhang, H.; Tang, J.; Liu, X.P.; Wang, Y.; Yu, W.; Peng, W.Y.; Fang, F.; Ma, D.F.; Wei, Z.J.; Hu, L.Y. Hydrogen sulfide promotes root organogenesis in Ipomoea batatas, Salix matsudana and Glycine max. J. Integr. Plant Biol. 2009, 51, 1086-1094. [CrossRef]

34. Chen, J.; Wu, F.H.; Wang, W.H.; Zheng, C.J.; Lin, G.H.; Dong, X.J.; He, J.X.; Pei, Z.M.; Zheng, H.L. Hydrogen sulphide enhances photosynthesis through promoting chloroplast biogenesis, photosynthetic enzyme expression, and thiol redox modification in Spinacia oleracea seedlings. J. Exp. Bot. 2011, 62, 4481-4493. [CrossRef] [PubMed]

35. Zhang, H.; Tan, Z.Q.; Hu, L.Y.; Wang, S.H.; Luo, J.P.; Jones, R.L. Hydrogen sulfide alleviates aluminum toxicity in germinating wheat seedlings. J. Integr. Plant Biol. 2010, 52, 556-567. [CrossRef]

36. Wang, B.L.; Shi, L.; Li, Y.X.; Zhang, W.H. Boron toxicity is alleviated by hydrogen sulfide in cucumber (Cucumis sativus L.) seedlings. Planta 2010, 231, 1301-1309. [CrossRef]

37. Li, L.; Wang, Y.; Shen, W. Roles of hydrogen sulfide and nitric oxide in the alleviation of cadmium-induced oxidative damage in alfalfa seedling roots. BioMetals 2012, 25, 617-631. [CrossRef]

38. Sun, J.; Wang, R.; Zhang, X.; Yu, Y.; Zhao, R.; Li, Z.; Chen, S. Hydrogen sulfide alleviates cadmium toxicity through regulations of cadmium transport across the plasma and vacuolar membranes in Populus euphratica cells. Plant Physiol. Biochem. PPB 2013, 65, 67-74. [CrossRef]

39. Shen, J.; Xing, T.; Yuan, H.; Liu, Z.; Jin, Z.; Zhang, L.; Pei, Y. Hydrogen Sulfide Improves Drought Tolerance in Arabidopsis thaliana by MicroRNA Expressions. PLoS ONE 2013, 8, e77047. [CrossRef]

40. Fang, H.; Liu, Z.; Jin, Z.; Zhang, L.; Liu, D.; Pei, Y. An emphasis of hydrogen sulfide-cysteine cycle on enhancing the tolerance to chromium stress in Arabidopsis. Environ. Pollut. (Barking Essex 1987) 2016, 213, 870-877. [CrossRef]

41. Li, Z.G.; Gong, M.; Xie, H.; Yang, L.; Li, J. Hydrogen sulfide donor sodium hydrosulfide-induced heat tolerance in tobacco (Nicotiana tabacum L) suspension cultured cells and involvement of $\mathrm{Ca}(2+)$ and calmodulin. Plant Sci. Int. J. Exp. Plant Biol. 2012, 185, 185-189. [CrossRef]

42. Shi, H.; Ye, T.; Chan, Z. Exogenous application of hydrogen sulfide donor sodium hydrosulfide enhanced multiple abiotic stress tolerance in bermudagrass (Cynodon dactylon (L). Pers.). Plant Physiol. Biochem. 2013, 71, 226-234. [CrossRef]

43. Papanatsiou, M.; Scuffi, D.; Blatt, M.R.; Garcia-Mata, C. Hydrogen sulfide regulates inward-rectifying k+ channels in conjunction with stomatal closure. Plant Physiol. 2015, 168, 29-35. [CrossRef] [PubMed]

44. Scuffi, D.; Nunez, A.; Laspina, N.; Gotor, C.; Lamattina, L.; Garcia-Mata, C. Hydrogen sulfide generated by L-cysteine desulfhydrase acts upstream of nitric oxide to modulate ABA-dependent stomatal closure. Plant Physiol. 2014, 166, 2065-2076. [CrossRef] [PubMed]

45. Lisjak, M.; Srivastava, N.; Teklic, T.; Civale, L.; Lewandowski, K.; Wilson, I.; Wood, M.E.; Whiteman, M.; Hancock, J.T. A novel hydrogen sulfide donor causes stomatal opening and reduces nitric oxide accumulation. Plant Physiol. Biochem. 2010, 48, 931-935. [CrossRef]

46. Garcia-Mata, C.; Lamattina, L. Hydrogen sulphide, a novel gasotransmitter involved in guard cell signalling. New Phytol. 2010, 188, 977-984. [CrossRef]

47. Jin, Z.; Xue, S.; Luo, Y.; Tian, B.; Fang, H.; Li, H.; Pei, Y. Hydrogen sulfide interacting with abscisic acid in stomatal regulation responses to drought stress in Arabidopsis. Plant Physiol. Biochem. 2013, 62, 41-46. [CrossRef]

48. Dooley, F.D.; Nair, S.P.; Ward, P.D. Increased growth and germination success in plants following hydrogen sulfide administration. PLoS ONE 2013, 8, e62048. [CrossRef]

49. Zhang, H.; Hu, S.-L.; Zhang, Z.-J.; Hu, L.-Y.; Jiang, C.-X.; Wei, Z.-J.; Liu, J.; Wang, H.-L.; Jiang, S.-T. Hydrogen sulfide acts as a regulator of flower senescence in plants. Postharvest Biol. Technol. 2011, 60, 251-257. [CrossRef]

50. Fang, T.; Cao, Z.; Li, J.; Shen, W.; Huang, L. Auxin-induced hydrogen sulfide generation is involved in lateral root formation in tomato. Plant Physiol. Biochem. 2014, 76, 44-51. [CrossRef] 
51. Chen, X.; Chen, Q.; Zhang, X.; Li, R.; Jia, Y.; Ef, A.A.; Jia, A.; Hu, L.; Hu, X. Hydrogen sulfide mediates nicotine biosynthesis in tobacco (Nicotiana tabacum) under high temperature conditions. Plant Physiol. Biochem. 2016, 104, 174-179. [CrossRef] [PubMed]

52. Wu, Y.C.; Wang, X.J.; Yu, L.; Chan, F.K.; Cheng, A.S.; Yu, J.; Sung, J.J.; Wu, W.K.; Cho, C.H. Hydrogen sulfide lowers proliferation and induces protective autophagy in colon epithelial cells. PLoS ONE 2012, 7, e37572. [CrossRef] [PubMed]

53. Zhang, M.; Shan, H.; Chang, P.; Wang, T.; Dong, W.; Chen, X.; Tao, L. Hydrogen sulfide offers neuroprotection on traumatic brain injury in parallel with reduced apoptosis and autophagy in mice. PLoS ONE 2014, 9, e87241. [CrossRef]

54. Diaz-Troya, S.; Perez-Perez, M.E.; Florencio, F.J.; Crespo, J.L. The role of TOR in autophagy regulation from yeast to plants and mammals. Autophagy 2008, 4, 851-865. [CrossRef]

55. Gwinn, D.M.; Shackelford, D.B.; Egan, D.F.; Mihaylova, M.M.; Mery, A.; Vasquez, D.S.; Turk, B.E.; Shaw, R.J. AMPK phosphorylation of raptor mediates a metabolic checkpoint. Mol. Cell 2008, 30, 214-226. [CrossRef] [PubMed]

56. Álvarez, C.; Garcia, I.; Moreno, I.; Perez-Perez, M.E.; Crespo, J.L.; Romero, L.C.; Gotor, C. Cysteine-generated sulfide in the cytosol negatively regulates autophagy and modulates the transcriptional profile in Arabidopsis. Plant Cell 2012, 24, 4621-4634. [CrossRef]

57. Laureano-Marin, A.M.; Moreno, I.; Romero, L.C.; Gotor, C. Negative Regulation of Autophagy by Sulfide Is Independent of Reactive Oxygen Species. Plant Physiol. 2016, 171, 1378-1391. [CrossRef] [PubMed]

58. Kabil, O.; Banerjee, R. Redox biochemistry of hydrogen sulfide. J. Biol. Chem. 2010, 285, $21903-21907$. [CrossRef]

59. Fukuto, J.M.; Carrington, S.J.; Tantillo, D.J.; Harrison, J.G.; Ignarro, L.J.; Freeman, B.A.; Chen, A.; Wink, D.A. Small molecule signaling agents: The integrated chemistry and biochemistry of nitrogen oxides, oxides of carbon, dioxygen, hydrogen sulfide, and their derived species. Chem. Res. Toxicol. 2012, 25, 769-793. [CrossRef]

60. Aroca, A.; Serna, A.; Gotor, C.; Romero, L.C. S-sulfhydration: A cysteine posttranslational modification in plant systems. Plant Physiol. 2015, 168, 334-342. [CrossRef]

61. Shan, C.; Wang, T.; Zhou, Y.; Wang, W. Hydrogen sulfide is involved in the regulation of ascorbate and glutathione metabolism by jasmonic acid in Arabidopsis thaliana. Biol. Plant. 2018, 62, 188-193. [CrossRef]

62. Shan, C.; Zhang, S.; Zhou, Y. Hydrogen sulfide is involved in the regulation of ascorbate-glutathione cycle by exogenous ABA in wheat seedling leaves under osmotic stress. Cereal Res. Commun. 2017, 45, 411-420. [CrossRef]

63. Xie, Z.-Z.; Liu, Y.; Bian, J.-S. Hydrogen Sulfide and Cellular Redox Homeostasis. Oxid. Med. Cell. Longev. 2016, 2016, 6043038. [CrossRef] [PubMed]

64. Yu, L.-X.; Zhang, C.-J.; Shang, H.-Q.; Wang, X.-F.; Wei, M.; Yang, F.-J.; Shi, Q.-H. Exogenous Hydrogen Sulfide Enhanced Antioxidant Capacity, Amylase Activities and Salt Tolerance of Cucumber Hypocotyls and Radicles. J. Integr. Agric. 2013, 12, 445-456. [CrossRef]

65. Li, Z.G. Analysis of some enzymes activities of hydrogen sulfide metabolism in plants. Methods Enzym. 2015, 555, 253-269. [CrossRef]

66. Kimura, Y.; Goto, Y.; Kimura, H. Hydrogen sulfide increases glutathione production and suppresses oxidative stress in mitochondria. Antioxid. Redox Signal. 2010, 12, 1-13. [CrossRef]

67. Singh, V.P.; Singh, S.; Kumar, J.; Prasad, S.M. Hydrogen sulfide alleviates toxic effects of arsenate in pea seedlings through up-regulation of the ascorbate-glutathione cycle: Possible involvement of nitric oxide. J. Plant Physiol. 2015, 181, 20-29. [CrossRef]

68. Stein, A.; Bailey, S.M. Redox biology of hydrogen sulfide: Implications for physiology, pathophysiology, and pharmacology. Redox Biol. 2013, 1, 32-39. [CrossRef]

69. Fotopoulos, V.; Christou, A.; Antoniou, C.; Manganaris, G.A. REVIEW ARTICLE Hydrogen sulphide: A versatile tool for the regulation of growth and defence responses in horticultural crops. J. Hortic. Sci. Biotechnol. 2015, 90, 227-234. [CrossRef]

70. Godfray, H.C.; Beddington, J.R.; Crute, I.R.; Haddad, L.; Lawrence, D.; Muir, J.F.; Pretty, J.; Robinson, S.; Thomas, S.M.; Toulmin, C. Food security: The challenge of feeding 9 billion people. Science 2010, 327, 812-818. [CrossRef] 
71. Hartle, M.D.; Pluth, M.D. A practical guide to working with $\mathrm{H}(2) \mathrm{S}$ at the interface of chemistry and biology. Chem. Soc. Rev. 2016, 45, 6108-6117. [CrossRef] [PubMed]

72. Fogo, J.K.; Popowsky, M. Spectrophotometric Determination of Hydrogen Sulfide. Anal. Chem. 1949, 21, 732-734. [CrossRef]

73. Cline, J.D. Spectrophotometric determination of hydrogen sulfide in natural waters. Limnol. Oceanogr. 1969, 14, 454-458. [CrossRef]

74. Shen, X.; Pattillo, C.B.; Pardue, S.; Bir, S.C.; Wang, R.; Kevil, C.G. Measurement of plasma hydrogen sulfide in vivo and in vitro. Free Radic. Biol. Med. 2011, 50, 1021-1031. [CrossRef] [PubMed]

75. Cao, X.; Ding, L.; Xie, Z.Z.; Yang, Y.; Whiteman, M.; Moore, P.K.; Bian, J.S. A Review of Hydrogen Sulfide Synthesis, Metabolism, and Measurement: Is Modulation of Hydrogen Sulfide a Novel Therapeutic for Cancer? Antioxid. Redox Signal. 2019, 31, 1-38. [CrossRef] [PubMed]

76. Shen, X.; Peter, E.A.; Bir, S.; Wang, R.; Kevil, C.G. Analytical measurement of discrete hydrogen sulfide pools in biological specimens. Free Radic. Biol. Med. 2012, 52, 2276-2283. [CrossRef]

77. Tan, B.; Jin, S.; Sun, J.; Gu, Z.; Sun, X.; Zhu, Y.; Huo, K.; Cao, Z.; Yang, P.; Xin, X.; et al. New method for quantification of gasotransmitter hydrogen sulfide in biological matrices by LC-MS/MS. Sci. Rep. 2017, 7, 46278. Available online: https://www.nature.com/articles/srep46278\#supplementary-information (accessed on 14 July 2020). [CrossRef]

78. Kage, S.; Nagata, T.; Kimura, K.; Kudo, K. Extractive alkylation and gas chromatographic analysis of sulfide. J. Forensic Sci. 1988, 33, 217-222.

79. Furne, J.; Saeed, A.; Levitt, M.D. Whole tissue hydrogen sulfide concentrations are orders of magnitude lower than presently accepted values. Am. J. Physiol. Regul. Integr. Comp. Physiol. 2008, 295, R1479-R1485. [CrossRef]

80. Takano, Y.; Echizen, H.; Hanaoka, K. Fluorescent Probes and Selective Inhibitors for Biological Studies of Hydrogen Sulfide- and Polysulfide-Mediated Signaling. Antioxid. Redox Signal. 2017, 27, 669-683. [CrossRef]

81. Lin, V.S.; Chen, W.; Xian, M.; Chang, C.J. Chemical probes for molecular imaging and detection of hydrogen sulfide and reactive sulfur species in biological systems. Chem. Soc. Rev. 2015, 44, 4596-4618. [CrossRef]

82. Takano, Y.; Hanaoka, K.; Shimamoto, K.; Miyamoto, R.; Komatsu, T.; Ueno, T.; Terai, T.; Kimura, H.; Nagano, T.; Urano, Y. Development of a reversible fluorescent probe for reactive sulfur species, sulfane sulfur, and its biological application. Chem. Commun. (Camb. Engl.) 2017, 53, 1064-1067. [CrossRef] [PubMed]

83. Dulac, M.; Melet, A.; Galardon, E. Reversible Detection and Quantification of Hydrogen Sulfide by Fluorescence Using the Hemoglobin I from Lucina pectinata. ACS Sens. 2018, 3, 2138-2144. [CrossRef] [PubMed]

84. Shang, X.; Li, J.; Feng, Y.; Chen, H.; Guo, W.; Zhang, J.; Wang, T.; Xu, X. Low-Cytotoxicity Fluorescent Probes Based on Anthracene Derivatives for Hydrogen Sulfide Detection. Front. Chem. 2018, 6, 202. [CrossRef]

85. Li, Y.-J.; Chen, J.; Xian, M.; Zhou, L.-G.; Han, F.X.; Gan, L.-J.; Shi, Z.-Q. In Site Bioimaging of Hydrogen Sulfide Uncovers Its Pivotal Role in Regulating Nitric Oxide-Induced Lateral Root Formation. PLoS ONE 2014, 9, e90340. [CrossRef]

86. Savage, J.C.; Gould, D.H. Determination of sulfide in brain tissue and rumen fluid by ion-interaction reversed-phase high-performance liquid chromatography. J. Chromatogr. 1990, 526, 540-545. [CrossRef]

87. Zhao, W.; Zhang, J.; Lu, Y.; Wang, R. The vasorelaxant effect of $\mathrm{H}(2) \mathrm{S}$ as a novel endogenous gaseous K(ATP) channel opener. EMBO J. 2001, 20, 6008-6016. [CrossRef]

88. Levitt, M.D.; Abdel-Rehim, M.S.; Furne, J. Free and acid-labile hydrogen sulfide concentrations in mouse tissues: Anomalously high free hydrogen sulfide in aortic tissue. Antioxid. Redox Signal. 2011, 15, 373-378. [CrossRef] [PubMed]

89. Bhuiyan, A.I.; Papajani, V.T.; Paci, M.; Melino, S. Glutathione-Garlic Sulfur Conjugates: Slow Hydrogen Sulfide Releasing Agents for Therapeutic Applications. Molecules 2015, 20, 1731. [CrossRef] [PubMed]

90. Lechuga, T.J.; Zhang, H.H.; Sheibani, L.; Karim, M.; Jia, J.; Magness, R.R.; Rosenfeld, C.R.; Chen, D.B. Estrogen Replacement Therapy in Ovariectomized Nonpregnant Ewes Stimulates Uterine Artery Hydrogen Sulfide Biosynthesis by Selectively Up-Regulating Cystathionine beta-Synthase Expression. Endocrinology 2015, 156, 2288-2298. [CrossRef]

91. Jin, Z.; Shen, J.; Qiao, Z.; Yang, G.; Wang, R.; Pei, Y. Hydrogen sulfide improves drought resistance in Arabidopsis thaliana. Biochem. Biophys. Res. Commun. 2011, 414, 481-486. [CrossRef] [PubMed] 
92. Birke, H.; Hildebrandt, T.M.; Wirtz, M.; Hell, R. Sulfide detoxification in plant mitochondria. Methods Enzym. 2015, 555, 271-286. [CrossRef]

93. Rennenberg, H.; Filner, P. Developmental changes in the potential for h(2)s emission in cucurbit plants. Plant Physiol. 1983, 71, 269-275. [CrossRef]

94. Jin, Z.; Wang, Z.; Yang, G.; Pei, Y. Diversity of hydrogen sulfide concentration in plant: A little spark to start a prairie fire. Sci. Bull. 2018, 63, 1314-1316. [CrossRef]

95. Wilinski, J.; Wilinski, B.; Somogyi, E.; Piotrowska, J.; Kameczura, T.; Zygmunt, M. Nicotine affects hydrogen sulfide concentrations in mouse kidney and heart but not in brain and liver tissues. Folia Med. Crac. 2017, 57, 55-64.

96. Chen, K.Y.; Morris, J.C. Kinetics of oxidation of aqueous sulfide by oxygen. Environ. Sci. Technol. 1972, 6, 529-537. [CrossRef]

97. Ríos-González, B.B.; Román-Morales, E.M.; Pietri, R.; López-Garriga, J. Hydrogen sulfide activation in hemeproteins: The sulfheme scenario. J. Inorg. Biochem. 2014, 133, 78-86. [CrossRef]

98. Filipovic, M.R. Persulfidation (S-sulfhydration) and H2S. Handb. Exp. Pharmacol. 2015, 230, 29-59. [CrossRef]

99. Mustafa, A.K.; Sikka, G.; Gazi, S.K.; Steppan, J.; Jung, S.M.; Bhunia, A.K.; Barodka, V.M.; Gazi, F.K.; Barrow, R.K.; Wang, R.; et al. Hydrogen sulfide as endothelium-derived hyperpolarizing factor sulfhydrates potassium channels. Circ. Res. 2011, 109, 1259-1268. [CrossRef]

100. Nishida, M.; Sawa, T.; Kitajima, N.; Ono, K.; Inoue, H.; Ihara, H.; Motohashi, H.; Yamamoto, M.; Suematsu, M.; Kurose, H.; et al. Hydrogen sulfide anion regulates redox signaling via electrophile sulfhydration. Nat. Chem. Biol. 2012, 8, 714-724. [CrossRef]

101. Toohey, J.I. Sulfur Signaling: Is the Agent Sulfide or Sulfane? Anal. Biochem. 2011, 413, 1-7. [CrossRef] [PubMed]

102. Aroca, A.; Schneider, M.; Scheibe, R.; Gotor, C.; Romero, L.C. Hydrogen Sulfide Regulates the Cytosolic/Nuclear Partitioning of Glyceraldehyde-3-Phosphate Dehydrogenase by Enhancing its Nuclear Localization. Plant Cell Physiol. 2017, 58, 983-992. [CrossRef] [PubMed]

103. Kimura, H. Physiological Roles of Hydrogen Sulfide and Polysulfides. Handb. Exp. Pharmacol. 2015, $230,61$. [PubMed]

104. Mustafa, A.K.; Gadalla, M.M.; Sen, N.; Kim, S.; Mu, W.; Gazi, S.K.; Barrow, R.K.; Yang, G.; Wang, R.; Snyder, S.H. H2S Signals Through Protein S-Sulfhydration. Sci. Signal. 2009, 2, ra72. [CrossRef] [PubMed]

105. Aroca, A.; Benito, J.M.; Gotor, C.; Romero, L.C. Persulfidation proteome reveals the regulation of protein function by hydrogen sulfide in diverse biological processes in Arabidopsis. J. Exp. Bot. 2017, 68, 4915-4927. [CrossRef]

106. Cuevasanta, E.; Möller, M.N.; Alvarez, B. Biological chemistry of hydrogen sulfide and persulfides. Arch. Biochem. Biophys. 2017, 617, 9-25. [CrossRef]

107. Aroca, A.; Gotor, C.; Romero, L.C. Hydrogen Sulfide Signaling in Plants: Emerging Roles of Protein Persulfidation. Front. Plant Sci. 2018, 9, 1369. [CrossRef] [PubMed]

108. Filipovic, M.R.; Zivanovic, J.; Alvarez, B.; Banerjee, R. Chemical Biology of H2S Signaling through Persulfidation. Chem. Rev. 2018, 118, 1253-1337. [CrossRef] [PubMed]

109. Modis, K.; Ju, Y.; Ahmad, A.; Untereiner, A.A.; Altaany, Z.; Wu, L.; Szabo, C.; Wang, R. S-Sulfhydration of ATP synthase by hydrogen sulfide stimulates mitochondrial bioenergetics. Pharmacol. Res. 2016, 113, 116-124. [CrossRef]

110. Untereiner, A.A.; Olah, G.; Modis, K.; Hellmich, M.R.; Szabo, C. H2S-induced S-sulfhydration of lactate dehydrogenase a (LDHA) stimulates cellular bioenergetics in HCT116 colon cancer cells. Biochem. Pharmacol. 2017, 136, 86-98. [CrossRef] [PubMed]

111. Papapetropoulos, A.; Pyriochou, A.; Altaany, Z.; Yang, G.; Marazioti, A.; Zhou, Z.; Jeschke, M.G.; Branski, L.K.; Herndon, D.N.; Wang, R. Hydrogen Sulfide Is an Endogenous Stimulator of Angiogenesis. Proc. Natl. Acad. Sci. USA 2009, 106, 21972. [CrossRef] [PubMed]

112. Zhao, K.; Ju, Y.; Li, S.; Al Tanny, Z.; Wang, R.; Yang, G. S-Sulfhydration of MEK1 Leads to PARP-1 Activation and DNA Damage Repair. EMBO Rep. 2014, 15, 792. [CrossRef] [PubMed]

113. Vandiver, M.S.; Paul, B.D.; Xu, R.; Karuppagounder, S.; Rao, F.; Snowman, A.M.; Seok Ko, H.; Il Lee, Y.; Dawson, V.L.; Dawson, T.M. Sulfhydration Mediates Neuroprotective Actions of Parkin. Nat. Commun. 2013, 4, 1626. [CrossRef] [PubMed] 
114. Guo, C.; Liang, F.; Shah Masood, W.; Yan, X. Hydrogen sulfide protected gastric epithelial cell from ischemia/reperfusion injury by Keap1 s-sulfhydration, MAPK dependent anti-apoptosis and NF-kappaB dependent anti-inflammation pathway. Eur. J. Pharmacol. 2014, 725, 70-78. [CrossRef] [PubMed]

115. Li, J.; Chen, S.; Wang, X.; Shi, C.; Liu, H.; Yang, J.; Shi, W.; Guo, J.; Jia, H. Hydrogen Sulfide Disturbs Actin Polymerization via S-Sulfhydration Resulting in Stunted Root Hair Growth. Plant Physiol. 2018, 178, 936-949. [CrossRef]

116. Jia, H.; Chen, S.; Liu, D.; Liesche, J.; Shi, C.; Wang, J.; Ren, M.; Wang, X.; Yang, J.; Shi, W.; et al. Ethylene-Induced Hydrogen Sulfide Negatively Regulates Ethylene Biosynthesis by Persulfidation of ACO in Tomato Under Osmotic Stress. Front. Plant Sci. 2018, 9, 1517. [CrossRef]

117. Sandalio, L.M.; Gotor, C.; Romero, L.C.; Romero-Puertas, M.C. Multilevel Regulation of Peroxisomal Proteome by Post-Translational Modifications. Int. J. Mol. Sci. 2019, 20, 4881. [CrossRef]

118. Olson, K.R. Hydrogen sulfide, reactive sulfur species and coping with reactive oxygen species. Free Radic. Biol. Med. 2019, 140, 74-83. [CrossRef]

119. Peng, H.; Zhang, Y.; Palmer, L.D.; Kehl-Fie, T.E.; Skaar, E.P.; Trinidad, J.C.; Giedroc, D.P. Hydrogen Sulfide and Reactive Sulfur Species Impact Proteome S-Sulfhydration and Global Virulence Regulation in Staphylococcus aureus. ACS Infect. Dis. 2017, 3, 744-755. [CrossRef]

120. Coletta, C.; Papapetropoulos, A.; Erdelyi, K.; Olah, G.; Módis, K.; Panopoulos, P.; Asimakopoulou, A.; Gerö, D.; Sharina, I.; Martin, E.; et al. Hydrogen sulfide and nitric oxide are mutually dependent in the regulation of angiogenesis and endothelium-dependent vasorelaxation. Proc. Natl. Acad. Sci. USA 2012, 109, 9161-9166. [CrossRef]

121. Nagpure, B.V.; Bian, J.-S. Interaction of Hydrogen Sulfide with Nitric Oxide in the Cardiovascular System. Oxid. Med. Cell. Longev. 2016, 2016, 16. [CrossRef] [PubMed]

122. Salmina, A.B.; Komleva, Y.K.; Szijártó, I.A.; Gorina, Y.V.; Lopatina, O.L.; Gertsog, G.E.; Filipovic, M.R.; Gollasch, M. H2S- and NO-Signaling Pathways in Alzheimer's Amyloid Vasculopathy: Synergism or Antagonism? Front. Physiol. 2015, 6, 361. [CrossRef] [PubMed]

123. Lo Faro, M.L.; Burkholz, T.; Whiteman, M.; Winyard, P. Hydrogen Sulfide and Nitric Oxide Crosstalk: Evidence for Hydrogen Sulfide Mediated Nitric Oxide Production from Nitrite. Free Radic. Biol. Med. 2010, 49, S117. [CrossRef]

124. Vermeiren, J.; Van de Wiele, T.; Van Nieuwenhuyse, G.; Boeckx, P.; Verstraete, W.; Boon, N. Sulfide- and nitrite-dependent nitric oxide production in the intestinal tract. Microb. Biotechnol. 2012, 5, 379-387. [CrossRef] [PubMed]

125. Predmore, B.L.; Julian, D.; Cardounel, A.J. Hydrogen sulfide increases nitric oxide production from endothelial cells by an akt-dependent mechanism. Front. Physiol. 2011, 2, 104. [CrossRef]

126. Altaany, Z.; Yang, G.; Wang, R. Crosstalk between hydrogen sulfide and nitric oxide in endothelial cells. J. Cell. Mol. Med. 2013, 17, 879-888. [CrossRef] [PubMed]

127. Vicente, J.B.; Colaço, H.G.; Mendes, M.I.S.; Sarti, P.; Leandro, P.; Giuffrè, A. NO· Binds Human Cystathionine $\beta$-Synthase Quickly and Tightly. J. Biol. Chem. 2014, 289, 8579. [CrossRef]

128. Garcia-Mata, C.; Lamattina, L. Nitric oxide and abscisic acid cross talk in guard cells. Plant Physiol. 2002, 128, 790-792. [CrossRef]

129. Bellin, D.; Asai, S.; Delledonne, M.; Yoshioka, H. Nitric oxide as a mediator for defense responses. Mol. Plant Microbe Interact. 2013, 26, 271-277. [CrossRef]

130. Silveira, N.M.; Frungillo, L.; Marcos, F.C.; Pelegrino, M.T.; Miranda, M.T.; Seabra, A.B.; Salgado, I.; Machado, E.C.; Ribeiro, R.V. Exogenous nitric oxide improves sugarcane growth and photosynthesis under water deficit. Planta 2016, 244, 181-190. [CrossRef]

131. Procházková, D.; Haisel, D.; Wilhelmová, N.; Pavlíková, D.; Száková, J. Effects of exogenous nitric oxide on photosynthesis. Photosynthetica 2013, 51, 483-489. [CrossRef]

132. Zhan, N.; Wang, C.; Chen, L.; Yang, H.; Feng, J.; Gong, X.; Ren, B.; Wu, R.; Mu, J.; Li, Y.; et al. S-Nitrosylation Targets GSNO Reductase for Selective Autophagy during Hypoxia Responses in Plants. Mol. Cell 2018, 71, 142-154. [CrossRef] [PubMed]

133. Dmitrieva, S.A.; Ponomareva, A.A.; Gurjanov, O.P.; Mazina, A.B.; Andrianov, V.V.; Iyudin, V.S.; Minibayeva, F.V. Spermine Induces Autophagy in Plants: Possible Role of NO and Reactive Oxygen Species. Dokl. Biochem. Biophys. 2018, 483, 341-343. [CrossRef] [PubMed] 
134. Seabra, A.B.; Oliveira, H.C. How nitric oxide donors can protect plants in a changing environment: What we know so far and perspectives. AIMS Mol. Sci. 2016, 3, 692-718. [CrossRef]

135. Zhang, H. Hydrogen Sulfide in Plant Biology. In Gasotransmitters in Plants. Signaling and Communication in Plants; Lamattina, L., García-Mata, C., Eds.; Springer: Cham, Switzerland, 2016.

136. Kaya, C.; Higgs, D.; Ashraf, M.; Alyemeni, M.N.; Ahmad, P. Integrative roles of nitric oxide and hydrogen sulfide in melatonin-induced tolerance of pepper (Capsicum annuum L.) plants to iron deficiency and salt stress alone or in combination. Physiol. Plant. 2020, 168, 256-277. [CrossRef]

137. Muñoz-Vargas, M.A.; González-Gordo, S.; Palma, J.M.; Corpas, F.J. Inhibition of NADP-malic enzyme activity by $\mathrm{H}(2) \mathrm{S}$ and NO in sweet pepper (Capsicum annuum L.) fruits. Physiol. Plant. 2020, 168, 278-288. [CrossRef]

138. Lindermayr, C.; Saalbach, G.; Durner, J. Proteomic Identification of S-Nitrosylated Proteins in Arabidopsis. Plant Physiol. 2005, 137, 921-930. [CrossRef]

139. Begara-Morales, J.C.; Sánchez-Calvo, B.; Chaki, M.; Valderrama, R.; Mata-Pérez, C.; López-Jaramillo, J.; Padilla, M.N.; Carreras, A.; Corpas, F.J.; Barroso, J.B. Dual regulation of cytosolic ascorbate peroxidase (APX) by tyrosine nitration and S-nitrosylation. J. Exp. Bot. 2014, 65, 527-538. [CrossRef]

140. Whiteman, M.; Li, L.; Kostetski, I.; Chu, S.H.; Siau, J.L.; Bhatia, M.; Moore, P.K. Evidence for the formation of a novel nitrosothiol from the gaseous mediators nitric oxide and hydrogen sulphide. Biochem. Biophys. Res. Commun. 2006, 343, 303-310. [CrossRef]

141. Eberhardt, M.; Dux, M.; Namer, B.; Miljkovic, J.; Cordasic, N.; Will, C.; Kichko, T.I.; de la Roche, J.; Fischer, M.; Suarez, S.A.; et al. H2S and NO cooperatively regulate vascular tone by activating a neuroendocrine HNO-TRPA1-CGRP signalling pathway. Nat. Commun. 2014, 5, 4381. [CrossRef]

142. Bailey, T.S.; Henthorn, H.A.; Pluth, M.D. The Intersection of NO and H2S: Persulfides Generate NO from Nitrite through Polysulfide Formation. Inorg. Chem. 2016, 55, 12618-12625. [CrossRef] [PubMed]

143. Marcolongo, J.P.; Venâncio, M.F.; Rocha, W.R.; Doctorovich, F.; Olabe, J.A. NO/H2S “Crosstalk” Reactions. The Role of Thionitrites (SNO-) and Perthionitrites (SSNO-). Inorg. Chem. 2019, 58, 14981-14997. [CrossRef] [PubMed]

144. Marcolongo, J.P.; Morzan, U.N.; Zeida, A.; Scherlis, D.A.; Olabe, J.A. Nitrosodisulfide [S2NO]- (perthionitrite) is a true intermediate during the "cross-talk" of nitrosyl and sulfide. Phys. Chem. Chem. Phys. 2016, 18, 30047-30052. [CrossRef] [PubMed]

145. Morikawa, T.; Kajimura, M.; Nakamura, T.; Hishiki, T.; Nakanishi, T.; Yukutake, Y.; Nagahata, Y.; Ishikawa, M.; Hattori, K.; Takenouchi, T.; et al. Hypoxic regulation of the cerebral microcirculation is mediated by a carbon monoxide-sensitive hydrogen sulfide pathway. Proc. Natl. Acad. Sci. USA 2012, 109, 1293-1298. [CrossRef]

146. Zhang, Q.Y.; Du, J.B.; Zhang, C.Y.; Tang, C.S. The regulation of carbon monoxide/heme oxygenase system by hydrogen sulfide in rats with hypoxic pulmonary hypertension. Zhonghua Jie He He Hu Xi Za Zhi 2004, 27, 659-663.

147. Majid, A.S.A.; Majid, A.M.S.A.; Yin, Z.Q.; Ji, D. Slow Regulated Release of H2S Inhibits Oxidative Stress Induced Cell Death by Influencing Certain Key Signaling Molecules. Neurochem. Res. 2013, 38, 1375-1393. [CrossRef]

148. Guo, K.; Xia, K.; Yang, Z.-M. Regulation of tomato lateral root development by carbon monoxide and involvement in auxin and nitric oxide. J. Exp. Bot. 2008, 59, 3443-3452. [CrossRef]

149. Lin, Y.-T.; Li, M.-Y.; Cui, W.-T.; Lu, W.; Shen, W.-B. Haem oxygenase-1 is involved in hydrogen sulfide-induced cucumber adventitious root formation. J. Plant Growth Regul. 2012, 31, 519-528. [CrossRef]

150. Fang, T.; Li, J.; Cao, Z.; Chen, M.; Shen, W.; Huang, L. Heme oxygenase-1 is involved in sodium hydrosulfide-induced lateral root formation in tomato seedlings. Plant Cell Rep. 2014, 33, 969-978. [CrossRef]

151. Li, Y.-J.; Shi, Z.-Q.; Gan, L.-J.; Chen, J. Hydrogen sulfide is a novel gasotransmitter with pivotal role in regulating lateral root formation in plants. Plant Signal. Behav. 2014, 9, e29127. [CrossRef]

152. Li, Z.G.; Luo, L.J.; Sun, Y.F. Signal crosstalk between nitric oxide and hydrogen sulfide may be involved in hydrogen peroxide-induced thermotolerance in maize seedlings. Russ. J. Plant Physiol. 2015, 62, 507-514. [CrossRef]

153. Mei, Y.; Chen, H.; Shen, W.; Shen, W.; Huang, L. Hydrogen peroxide is involved in hydrogen sulfide-induced lateral root formation in tomato seedlings. BMC Plant Biol. 2017, 17, 162. [CrossRef]

154. Ma, Y.; Zhang, W.; Niu, J.; Ren, Y.; Zhang, F. Hydrogen sulfide may function downstream of hydrogen peroxide in salt stress-induced stomatal closure in Vicia faba. Funct. Plant Biol. 2019, 46, 136-145. [CrossRef] 
155. Li, Z.; Zhu, Y.; He, X.; Yong, B.; Peng, Y.; Zhang, X.; Ma, X.; Yan, Y.; Huang, L.; Nie, G. The hydrogen sulfide, a downstream signaling molecule of hydrogen peroxide and nitric oxide, involves spermidine-regulated transcription factors and antioxidant defense in white clover in response to dehydration. Environ. Exp. Bot. 2019, 161, 255-264. [CrossRef]

156. Kabała, K.; Zboińska, M.; Głowiak, D.; Reda, M.; Jakubowska, D.; Małgorzata, J. Interaction between the signaling molecules hydrogen sulfide and hydrogen peroxide and their role in vacuolar $\mathrm{H}+-$ ATPase regulation in cadmium-stressed cucumber roots. Physiol. Plant. 2019, 166, 688-704. [CrossRef] [PubMed]

157. Bestetti, S.; Medraño-Fernandez, I.; Galli, M.; Ghitti, M.; Bienert, G.P.; Musco, G.; Orsi, A.; Rubartelli, A.; Sitia, R. A persulfidation-based mechanism controls aquaporin-8 conductance. Sci. Adv. 2018, 4, eaar5770. [CrossRef] [PubMed]

158. Lin, V.S.; Lippert, A.R.; Chang, C.J. Cell-trappable fluorescent probes for endogenous hydrogen sulfide signaling and imaging H2O2-dependent H2S production. Proc. Natl. Acad. Sci. USA 2013, 110, 7131-7135. [CrossRef]

159. Feng, A.; Ling, C.; Xin-duo, L.; Bing, W.; San-wu, W.; Yu, Z.; Yu-lan, H.; You-en, Z. Hydrogen Sulfide Protects Human Cardiac Fibroblasts Against H2O2-induced Injury Through Regulating Autophagy-Related Proteins. Cell Transplant. 2018, 27, 1222-1234. [CrossRef]

160. Wu, L.; Yang, W.; Jia, X.; Yang, G.; Duridanova, D.; Cao, K.; Wang, R. Pancreatic islet overproduction of H2S and suppressed insulin release in Zucker diabetic rats. Lab. Investig. 2008, 89, 59. [CrossRef]

161. Yang, G.; Yang, W.; Wu, L.; Wang, R. H2S, Endoplasmic Reticulum Stress, and Apoptosis of Insulin-secreting Beta Cells. J. Biol. Chem. 2007, 282, 16567-16576. [CrossRef]

162. Yang, W.; Yang, G.; Jia, X.; Wu, L.; Wang, R. Activation of KATP channels by H2S in rat insulin-secreting cells and the underlying mechanisms. J. Physiol. 2005, 569, 519-531. [CrossRef]

163. Li, H.; Mani, S.; Cao, W.; Yang, G.; Lai, C.; Wu, L.; Wang, R. Interaction of hydrogen sulfide and estrogen on the proliferation of vascular smooth muscle cells. PLoS ONE 2012, 7, e41614. [CrossRef] [PubMed]

164. Li, H.; Mani, S.; Wu, L.; Fu, M.; Shuang, T.; Xu, C.; Wang, R. The interaction of estrogen and CSE/H2S pathway in the development of atherosclerosis. Am. J. Physiol. Heart Circ. Physiol. 2017, 312, H406-H414. [CrossRef] [PubMed]

165. Hine, C.; Kim, H.J.; Zhu, Y.; Harputlugil, E.; Longchamp, A.; Matos, M.S.; Ramadoss, P.; Bauerle, K.; Brace, L.; Asara, J.M.; et al. Hypothalamic-Pituitary Axis Regulates Hydrogen Sulfide Production. Cell Metab. 2017, 25, 1320-1333. [CrossRef]

166. Xie, Y.; Zhang, C.; Lai, D.; Sun, Y.; Samma, M.K.; Zhang, J.; Shen, W. Hydrogen sulfide delays GA-triggered programmed cell death in wheat aleurone layers by the modulation of glutathione homeostasis and heme oxygenase-1 expression. J. Plant Physiol. 2014, 171, 53-62. [CrossRef] [PubMed]

167. Tian, B.; Zhang, Y.; Jin, Z.; Liu, Z.; Pei, Y. Role of hydrogen sulfide in the methyl jasmonate response to cadmium stress in foxtail millet. Front. Biosci. (Landmark Ed.) 2017, 22, 530-538.

168. Hou, Z.; Wang, L.; Liu, J.; Hou, L.; Liu, X. Hydrogen sulfide regulates ethylene-induced stomatal closure in Arabidopsis thaliana. J. Integr. Plant Biol. 2013, 55, 277-289. [CrossRef]

169. Li, Z.-G. Synergistic effect of antioxidant system and osmolyte in hydrogen sulfide and salicylic acid crosstalk-induced heat tolerance in maize (Zea mays L.) seedlings. Plant Signal. Behav. 2015, 10, e1051278. [CrossRef]

170. Zhang, H.; Dou, W.; Jiang, C.X.; Wei, Z.J.; Liu, J.; Jones, R.L. Hydrogen Sulfide Stimulates $\beta$-Amylase Activity during Early Stages of Wheat Grain Germination. Plant Signal. Behav. 2010, 5, 1031. [CrossRef]

171. Jia, H.; Hu, Y.; Fan, T.; Li, J. Hydrogen sulfide modulates actin-dependent auxin transport via regulating ABPs results in changing of root development in Arabidopsis. Sci. Rep. 2015, 5, 8251. [CrossRef]

172. Shi, H.; Ye, T.; Han, N.; Bian, H.; Liu, X.; Chan, Z. Hydrogen sulfide regulates abiotic stress tolerance and biotic stress resistance in Arabidopsis. J. Integr. Plant Biol. 2015, 57, 628-640. [CrossRef] [PubMed]

173. Hou, Z.H.; Liu, J.; Hou, L.X.; Li, X.D.; Liu, X. H2S may function downstream of H2O2 in jasmonic acid-induced stomatal closure in Vicia faba. Chin. Bull. Bot. 2011, 46, 396-406.

174. Li, Z.G.; Xie, L.R.; Li, X.J. Hydrogen sulfide acts as a downstream signal molecule in salicylic acid-induced heat tolerance in maize (Zea mays L.) seedlings. J. Plant Physiol. 2015, 177, 121-127. [CrossRef] [PubMed]

175. Liu, J.; Hou, L.; Liu, G.; Liu, X.; Wang, X. Hydrogen sulfide induced by nitric oxide mediates ethylene-induced stomatal closure of Arabidopsis thaliana. Chin. Sci. Bull. 2011, 56, 3547-3553. [CrossRef] 
176. Liu, J.; Hou, Z.-H.; Liu, G.-H.; Hou, L.-X.; Liu, X. Hydrogen Sulfide May Function Downstream of Nitric Oxide in Ethylene-Induced Stomatal Closure in Vicia faba L. J. Integr. Agric. 2012, 11, 1644-1653. [CrossRef]

177. Li, T.-T.; Li, Z.-R.; Hu, K.-D.; Hu, L.-Y.; Chen, X.-Y.; Li, Y.-H.; Yang, Y.; Yang, F.; Zhang, H. Hydrogen Sulfide Alleviates Kiwifruit Ripening and Senescence by Antagonizing Effect of Ethylene. HortScience 2017, 52, 1556-1562. [CrossRef]

178. Ma, D.; Ding, H.; Wang, C.; Qin, H.; Han, Q.; Hou, J.; Lu, H.; Xie, Y.; Guo, T. Alleviation of Drought Stress by Hydrogen Sulfide Is Partially Related to the Abscisic Acid Signaling Pathway in Wheat. PLoS ONE 2016, 11, e0163082. [CrossRef]

179. Honda, K.; Yamada, N.; Yoshida, R.; Ihara, H.; Sawa, T.; Akaike, T.; Iwai, S. 8-Mercapto-Cyclic GMP Mediates Hydrogen Sulfide-Induced Stomatal Closure in Arabidopsis. Plant Cell Physiol. 2015, 56, 1481-1489. [CrossRef]

180. Scuffi, D.; Nietzel, T.; Di Fino, L.M.; Meyer, A.J.; Lamattina, L.; Schwarzländer, M.; Laxalt, A.M.; García-Mata, C. Hydrogen Sulfide Increases Production of NADPH Oxidase-Dependent Hydrogen Peroxide and Phospholipase D-Derived Phosphatidic Acid in Guard Cell Signaling. Plant Physiol. 2018, 176, 2532-2542. [CrossRef]

181. Lang, Z.; Zuo, J. Say "NO" to ABA signaling in guard cells by S-nitrosylation of OST1. Sci. China Life Sci. 2015, 58, 313-314. [CrossRef]

182. Wang, P.; Du, Y.; Hou, Y.J.; Zhao, Y.; Hsu, C.C.; Yuan, F.; Zhu, X.; Tao, W.A.; Song, C.P.; Zhu, J.K. Nitric oxide negatively regulates abscisic acid signaling in guard cells by S-nitrosylation of OST1. Proc. Natl. Acad. Sci. USA 2015, 112, 613-618. [CrossRef] [PubMed]

183. Shen, J.; Zhang, J.; Zhou, M.; Zhou, H.; Cui, B.; Gotor, C.; Romero, L.C.; Fu, L.; Yang, J.; Foyer, C.H.; et al. Persulfidation-based Modification of Cysteine Desulfhydrase and the NADPH Oxidase RBOHD Controls Guard Cell Abscisic Acid Signaling. Plant Cell 2020, 32, 1000-1017. [CrossRef] [PubMed]

184. Wedmann, R.; Onderka, C.; Wei, S.; Szijarto, I.A.; Miljkovic, J.L.; Mitrovic, A.; Lange, M.; Savitsky, S.; Yadav, P.K.; Torregrossa, R.; et al. Improved tag-switch method reveals that thioredoxin acts as depersulfidase and controls the intracellular levels of protein persulfidation. Chem. Sci. 2016, 7, 3414-3426. [CrossRef]

185. Mitchell, D.A.; Morton, S.U.; Fernhoff, N.B.; Marletta, M.A. Thioredoxin is required for S-nitrosation of procaspase-3 and the inhibition of apoptosis in Jurkat cells. Proc. Natl. Acad. Sci. USA 2007, 104, 11609-11614. [CrossRef] [PubMed]

186. Astier, J.; Kulik, A.; Koen, E.; Besson-Bard, A.; Bourque, S.; Jeandroz, S.; Lamotte, O.; Wendehenne, D. Protein S-nitrosylation: What's going on in plants? Free Radic. Biol. Med. 2012, 53, 1101-1110. [CrossRef]

187. Bedhomme, M.; Adamo, M.; Marchand, C.H.; Couturier, J.; Rouhier, N.; Lemaire, S.D.; Zaffagnini, M.; Trost, P. Glutathionylation of cytosolic glyceraldehyde-3-phosphate dehydrogenase from the model plant Arabidopsis thaliana is reversed by both glutaredoxins and thioredoxins in vitro. Biochem. J. 2012, 445, 337-347. [CrossRef] [PubMed]

188. Dóka, É.; Pader, I.; Bíró, A.; Johansson, K.; Cheng, Q.; Ballagó, K.; Prigge, J.R.; Pastor-Flores, D.; Dick, T.P.; Schmidt, E.E.; et al. A novel persulfide detection method reveals protein persulfide- and polysulfide-reducing functions of thioredoxin and glutathione systems. Sci. Adv. 2016, 2, e1500968. [CrossRef]

189. Mao, Z.; Huang, Y.; Zhang, Z.; Yang, X.; Zhang, X.; Huang, Y.; Sawada, N.; Mitsui, T.; Takeda, M.; Yao, J. Pharmacological levels of hydrogen sulfide inhibit oxidative cell injury through regulating the redox state of thioredoxin. Free Radic. Biol. Med. 2019, 134, 190-199. [CrossRef]

190. Matz, H.; Orion, E.; Wolf, R. Balneotherapy in dermatology. Dermatol. Ther. 2003, 16, 132-140. [CrossRef]

191. Moss, G.A. Water and health: A forgotten connection? Perspect. Public Health 2010, 130, 227-232. [CrossRef]

192. Omar, S.H.; Al-Wabel, N.A. Organosulfur compounds and possible mechanism of garlic in cancer. Saudi Pharm. J. SPJ Off. Publ. Saudi Pharm. Soc. 2010, 18, 51-58. [CrossRef] [PubMed]

193. Banerjee, S.K.; Maulik, S.K. Effect of garlic on cardiovascular disorders: A review. Nutr. J. $2002,1,4$. [CrossRef] [PubMed]

194. Benavides, G.A.; Squadrito, G.L.; Mills, R.W.; Patel, H.D.; Isbell, T.S.; Patel, R.P.; Darley-Usmar, V.M.; Doeller, J.E.; Kraus, D.W. Hydrogen sulfide mediates the vasoactivity of garlic. Proc. Natl. Acad. Sci. USA 2007, 104, 17977-17982. [CrossRef] [PubMed]

195. Rose, P.; Moore, P.K.; Whiteman, M.; Zhu, Y.Z. An Appraisal of Developments in Allium Sulfur Chemistry: Expanding the Pharmacopeia of Garlic. Molecules 2019, 24, 4006. [CrossRef] [PubMed] 
196. Zhang, J.-Y.; Ding, Y.-P.; Wang, Z.; Kong, Y.; Gao, R.; Chen, G. Hydrogen sulfide therapy in brain diseases: From bench to bedside. Med. Gas Res. 2017, 7, 113-119. [CrossRef] [PubMed]

197. Bin, P.; Huang, R.; Zhou, X. Oxidation Resistance of the Sulfur Amino Acids: Methionine and Cysteine. BioMed Res. Int. 2017, 2017, 6. [CrossRef]

198. Yoshida, S.; Yamahara, K.; Kume, S.; Koya, D.; Yasuda-Yamahara, M.; Takeda, N.; Osawa, N.; Chin-Kanasaki, M.; Adachi, Y.; Nagao, K.; et al. Role of dietary amino acid balance in diet restriction-mediated lifespan extension, renoprotection, and muscle weakness in aged mice. Aging Cell 2018, 17, e12796. [CrossRef]

199. Kabil, O.; Vitvitsky, V.; Banerjee, R. Sulfur as a Signaling Nutrient Through Hydrogen Sulfide. Annu. Rev. Nutr. 2014, 34, 171-205. [CrossRef]

200. Miller, D.L.; Roth, M.B. Hydrogen sulfide increases thermotolerance and lifespan in Caenorhabditis elegans. Proc. Natl. Acad. Sci. USA 2007, 104, 20618-20622. [CrossRef]

201. Dong, Z.; Sinha, R.; Richie, J.P., Jr. Disease prevention and delayed aging by dietary sulfur amino acid restriction: Translational implications. Ann. N. Y. Acad. Sci. 2018, 1418, 44-55. [CrossRef]

202. Ji, X.; Pan, Z.; Li, C.; Kang, T.; De La Cruz, L.K.C.; Yang, L.; Yuan, Z.; Ke, B.; Wang, B. Esterase-Sensitive and $\mathrm{pH}$-Controlled Carbon Monoxide Prodrugs for Treating Systemic Inflammation. J. Med. Chem. 2019, 62, 3163-3168. [CrossRef] [PubMed]

203. Liang, H.; Nacharaju, P.; Friedman, A.; Friedman, J.M. Nitric oxide generating/releasing materials. Future Sci. OA 2015, 1, FSO54. [CrossRef] [PubMed]

204. Qin, L.; Gao, H. The application of nitric oxide delivery in nanoparticle-based tumor targeting drug delivery and treatment. Asian J. Pharm. Sci. 2019, 14, 380-390. [CrossRef] [PubMed]

205. Wallace, J.L.; Nagy, P.; Feener, T.D.; Allain, T.; Ditrói, T.; Vaughan, D.J.; Muscara, M.N.; de Nucci, G.; Buret, A.G. A proof-of-concept, Phase 2 clinical trial of the gastrointestinal safety of a hydrogen sulfide-releasing anti-inflammatory drug. Br. J. Pharmacol. 2020, 177, 769-777. [CrossRef] [PubMed]

206. Wallace, J.L.; Vaughan, D.; Dicay, M.; MacNaughton, W.K.; de Nucci, G. Hydrogen Sulfide-Releasing Therapeutics: Translation to the Clinic. Antioxid. Redox Signal. 2018, 28, 1533-1540. [CrossRef]

207. Nabeebaccus, A.A.; Shah, A.M. Hydrogen Sulfide Therapy Promotes Beneficial Systemic Effects in Experimental Heart Failure. JACC Basic Transl. Sci. 2018, 3, 810-812. [CrossRef]

208. DiNicolantonio, J.J.; OKeefe, J.H.; McCarty, M.F. Boosting endogenous production of vasoprotective hydrogen sulfide via supplementation with taurine and N-acetylcysteine: A novel way to promote cardiovascular health. Open Heart 2017, 4, e000600. [CrossRef]

209. Zhou, J.; Lv, X.-H.; Fan, J.-J.; Dang, L.-Y.; Dong, K.; Gao, B.; Song, A.-Q.; Wu, W.-N. GYY4137 Promotes Mice Feeding Behavior via Arcuate Nucleus Sulfur-Sulfhydrylation and AMPK Activation. Front. Pharmacol. 2018, 9, 966. [CrossRef]

210. Zivanovic, J.; Kouroussis, E.; Kohl, J.B.; Adhikari, B.; Bursac, B.; Schott-Roux, S.; Petrovic, D.; Miljkovic, J.L.; Thomas-Lopez, D.; Jung, Y.; et al. Selective Persulfide Detection Reveals Evolutionarily Conserved Antiaging Effects of S-Sulfhydration. Cell Metab. 2019, 30, 1152-1170.e13. [CrossRef]

211. Wallace, J.L.; Dicay, M.; McKnight, W.; Martin, G.R. Hydrogen sulfide enhances ulcer healing in rats. FASEB J. 2007, 21, 4070-4076. [CrossRef]

212. Magierowski, M.; Magierowska, K.; Hubalewska-Mazgaj, M.; Sliwowski, Z.; Ginter, G.; Pajdo, R.; Chmura, A.; Kwiecien, S.; Brzozowski, T. Carbon monoxide released from its pharmacological donor, tricarbonyldichlororuthenium (II) dimer, accelerates the healing of pre-existing gastric ulcers. Br. J. Pharmacol. 2017, 174, 3654-3668. [CrossRef] [PubMed]

213. Polhemus, D.J.; Li, Z.; Pattillo, C.B.; Gojon, G., Sr.; Gojon, G., Jr.; Giordano, T.; Krum, H. A novel hydrogen sulfide prodrug, SG1002, promotes hydrogen sulfide and nitric oxide bioavailability in heart failure patients. Cardiovasc. Ther. 2015, 33, 216-226. [CrossRef] [PubMed]

214. Hu, H.; Shen, W.; Li, P. Effects of hydrogen sulphide on quality and antioxidant capacity of mulberry fruit. Int. J. Food Sci. Technol. 2014, 49, 399-409. [CrossRef]

215. Hu, H.; Liu, D.; Li, P.; Shen, W. Hydrogen sulfide delays leaf yellowing of stored water spinach (Ipomoea aquatica) during dark-induced senescence by delaying chlorophyll breakdown, maintaining energy status and increasing antioxidative capacity. Postharvest Biol. Technol. 2015, 108, 8-20. [CrossRef]

216. Zhu, L.; Wang, W.; Shi, J.; Zhang, W.; Shen, Y.; Du, H.; Wu, S. Hydrogen sulfide extends the postharvest life and enhances antioxidant activity of kiwifruit during storage. J. Sci. Food Agric. 2014, 94, 2699-2704. [CrossRef] 
217. Li, Z.R.; Hu, K.; Zhang, F.Q.; Li, S.P.; Hu, L.Y.; Li, Y.H.; Wang, S.H.; Zhang, H. Hydrogen Sulfide Alleviates Dark-promoted Senescence in Postharvest Broccoli. HortScience 2015, 50, 416-420. [CrossRef]

218. Yao, G.-F.; Wei, Z.-Z.; Li, T.-T.; Tang, J.; Huang, Z.-Q.; Yang, F.; Li, Y.-H.; Han, Z.; Hu, F.; Hu, L.-Y.; et al. Modulation of Enhanced Antioxidant Activity by Hydrogen Sulfide Antagonization of Ethylene in Tomato Fruit Ripening. J. Agric. Food Chem. 2018, 66, 10380-10387. [CrossRef]

219. Ge, Y.; Hu, K.D.; Wang, S.S.; Hu, L.Y.; Chen, X.Y.; Li, Y.H.; Yang, Y.; Yang, F.; Zhang, H. Hydrogen sulfide alleviates postharvest ripening and senescence of banana by antagonizing the effect of ethylene. PLOS ONE 2017, 12, e0180113. [CrossRef]

220. Chang, Z.; Jingying, S.; Liqin, Z.; Changle, L.; Qingguo, W. Cooperative effects of hydrogen sulfide and nitric oxide on delaying softening and decay of strawberry. Int. J. Agric. Biol. Eng. 2014, 7, 114-122.

221. Mukherjee, S. Recent advancements in the mechanism of nitric oxide signaling associated with hydrogen sulfide and melatonin crosstalk during ethylene-induced fruit ripening in plants. Nitric Oxide Biol. Chem. Off. J. Nitric Oxide Soc. 2019, 82, 25-34. [CrossRef]

222. Li, Z.-G.; Min, X.; Zhou, Z.-H. Hydrogen Sulfide: A Signal Molecule in Plant Cross-Adaptation. Front. Plant Sci. 2016, 7, 1621. [CrossRef] [PubMed]

223. Álvarez, C.; Bermudez, M.A.; Romero, L.C.; Gotor, C.; Garcia, I. Cysteine homeostasis plays an essential role in plant immunity. New Phytol. 2012, 193, 165-177. [CrossRef] [PubMed]

224. Jin, Z.; Sun, L.; Yang, G.; Pei, Y. Hydrogen Sulfide Regulates Energy Production to Delay Leaf Senescence Induced by Drought Stress in Arabidopsis. Front. Plant Sci. 2018, 9, 1722. [CrossRef]

225. Thompson, C.R.; Kats, G. Effects of continuous hydrogen sulfide fumigation on crop and forest plants. Environ. Sci. Technol. 1978, 12, 550-553. [CrossRef]

(C) 2020 by the authors. Licensee MDPI, Basel, Switzerland. This article is an open access article distributed under the terms and conditions of the Creative Commons Attribution (CC BY) license (http://creativecommons.org/licenses/by/4.0/). 